\title{
Acetylcholine Modulates Cerebellar Granule Cell Spiking by Regulating the Balance of Synaptic Excitation and Inhibition
}

\author{
Taylor R. Fore, Benjamin N. Taylor, Nicolas Brunel, and @Court Hull \\ Department of Neurobiology, Duke University Medical School, Durham, North Carolina 27710
}

\begin{abstract}
Sensorimotor integration in the cerebellum is essential for refining motor output, and the first stage of this processing occurs in the granule cell layer. Recent evidence suggests that granule cell layer synaptic integration can be contextually modified, although the circuit mechanisms that could mediate such modulation remain largely unknown. Here we investigate the role of ACh in regulating granule cell layer synaptic integration in male rats and mice of both sexes. We find that Golgi cells, interneurons that provide the sole source of inhibition to the granule cell layer, express both nicotinic and muscarinic cholinergic receptors. While acute ACh application can modestly depolarize some Golgi cells, the net effect of longer, optogenetically induced ACh release is to strongly hyperpolarize Golgi cells. Golgi cell hyperpolarization by ACh leads to a significant reduction in both tonic and evoked granule cell synaptic inhibition. ACh also reduces glutamate release from mossy fibers by acting on presynaptic muscarinic receptors. Surprisingly, despite these consistent effects on Golgi cells and mossy fibers, ACh can either increase or decrease the spike probability of granule cells as measured by noninvasive cell-attached recordings. By constructing an integrate-and-fire model of granule cell layer population activity, we find that the direction of spike rate modulation can be accounted for predominately by the initial balance of excitation and inhibition onto individual granule cells. Together, these experiments demonstrate that $\mathrm{ACh}$ can modulate population-level granule cell responses by altering the ratios of excitation and inhibition at the first stage of cerebellar processing.
\end{abstract}

Key words: acetylcholine; cerebellum; EI balance; Golgi cell; granule cell; synaptic integration

Significance Statement

The cerebellum plays a key role in motor control and motor learning. While it is known that behavioral context can modify motor learning, the circuit basis of such modulation has remained unclear. Here we find that a key neuromodulator, $\mathrm{ACh}$, can alter the balance of excitation and inhibition at the first stage of cerebellar processing. These results suggest that ACh could play a key role in altering cerebellar learning by modifying how sensorimotor input is represented at the input layer of the cerebellum.

\section{Introduction}

To coordinate movements and learn sensorimotor associations, the cerebellum must integrate signals across a variety of modalities and timescales (Mauk and Buonomano, 2004; Ito, 2006, 2012; Giovannucci et al., 2017; Wagner et al., 2017). These signals are conveyed to the cerebellum via mossy fiber projections that form excitatory connections onto a much larger network of granule cells. The divergence from mossy fibers to granule cells has

Received Sept. 5, 2019; revised Feb. 3, 2020; accepted Feb. $20,2020$.

Author contributions: T.R.F., B.N.T., N.B., and C.H. designed research; T.R.F., B.N.T., and C.H. performed research; T.R.F., B.N.T., and C.H. analyzed data; T.R.F., N.B., and C.H. edited the paper; T.R.F., B.N.T., and C.H. wrote the paper.

This work was supported by National Institutes of Health National Institute of Neurological Disorders and Stroke Grant5R01NS096289-02, National Science Foundation Grant DGF1106401, the Sloan Foundation, and the Whitehall Foundation. We thank Dr. Lindsey Glickfeld and members of the C.H. and Glickfeld laboratories for input and technical assistance throughout the project.

The authors declare no competing financial interests.

Correspondence should be addressed to Court Hull at Hull@neuro.duke.edu.

https://doi.org/10.1523/JNEUROSCI.2148-19.2020

Copyright $\odot 2020$ the authors long been hypothesized to enable expansion recoding that enhances pattern separation and increases the encoding capacity of the network (Marr, 1969; Albus, 1971; Cayco-Gajic et al., 2017; Gilmer and Person, 2017).

While classical models of granule cell layer function posit rigid integration rules dictated by the anatomical pattern of mossy fiber to granule cell connectivity, recent studies have demonstrated that the granule cell layer can be contextually modified during behavior. Specifically, granule cell responses to certain sensory modalities can be suppressed during locomotion (Ozden et al., 2012). Moreover, associative learning can be enhanced during locomotion via circuit modulation thought to occur in the granule cell layer (Albergaria et al., 2018). Such contextual modification of granule cell responses may allow for both the enhancement of behaviorally relevant stimuli that should be learned, as well as suppression of information that should not be learned. However, the cellular mechanisms that enable such context-dependent regulation are largely unknown. 
Throughout the brain, neuromodulators play a key role in contextual circuit regulation (Letzkus et al., 2011; Froemke et al., 2013; Kuchibhotla et al., 2017). In the cerebellum, there are prominent ACh projections that terminate in the granule cell layer (Jaarsma et al., 1997). Moreover, immunohistochemical studies have shown both nicotinic and muscarinic receptors in the cerebellar cortex (Neustadt et al., 1988; Dominguez del Toro et al., 1994; Nakayama et al., 1997; Dominguez de Toro et al., 1997; Turner and Kellar, 2005). These anatomical observations suggest that ACh could be a key regulator of cerebellar processing and cerebellar-dependent behaviors. Indeed, behavioral studies have demonstrated cholinergic enhancement of the optokinetic reflex and vestibulo-ocular reflex (Tan and Collewijn, 1991, 1992; Prestori et al., 2013). However, it remains unknown both how endogenous levels of cerebellar ACh are modulated in vivo and how ACh acts at the synaptic and circuit levels to modify cerebellar cortical processing.

To test how ACh acts to modulate granule cell layer processing and synaptic integration, we have investigated both cell-autonomous and circuit-level effects of ACh by recording from granule cell layer neurons in an acute, in vitro brain slice preparation. We find that ACh predominantly leads to a prolonged suppression of Golgi cell activity via muscarinic receptor activation, in turn reducing both tonic and evoked synaptic inhibition onto granule cells. In addition, activation of presynaptic muscarinic receptors on mossy fibers leads to a reduction in granule cell excitation. Together, the coincident reduction in excitation and inhibition increases spike probability in some granule cells, while reducing spike probability in others. A population-level integrate-and-fire model of granule cell layer synaptic processing reveals that the direction of modulation depends on the relative balance of excitation and inhibition for individual granule cells. Specifically, we find that the activity of granule cells with the most inhibition is preferentially enhanced by $\mathrm{ACh}$, whereas the activity of granule cells with little inhibition is largely suppressed. Thus, these data suggest that $\mathrm{ACh}$ can act to enhance the reliability of granule cells that are significantly inhibited in response to specific mossy fiber input. Such modulation would be well suited to enhance the responses of granule cells that receive stimulus-specific inhibition (Precht and Llinás, 1969) without expanding the overall population response.

\section{Materials and Methods}

Acute slices and recordings. Acute sagittal slices $(250 \mu \mathrm{m})$ were prepared from the cerebellar vermis of Sprague Dawley rats (20- to 25-d-old males, Charles River) and ChAT-IRES-Cre mice (B6;129S6-Chat ${ }^{\text {tm2(cre)Lowl } / \text { J, }}$ The Jackson Laboratory, P40-P60, males and females). Slices were cut in an ice-cold potassium cutting solution (Dugué et al., 2005) consisting of the following (in mM): $130 \mathrm{~K}$-gluconate, $15 \mathrm{KCl}, 0.05 \mathrm{EGTA}, 20 \mathrm{HEPES}$, 25 glucose ( $\mathrm{pH} 7.4,315 \mathrm{mmol} / \mathrm{kg}$ ), and were transferred to an incubation chamber containing aCSF comprised of the following (in mM): $125 \mathrm{NaCl}$, $26 \mathrm{NaHCO}_{3}, 1.25 \mathrm{NaH}_{2} \mathrm{PO}_{4}, 2.5 \mathrm{KCl}, 2 \mathrm{CaCl}_{2}, 1 \mathrm{MgCl}_{2}$, and 25 glucose $(\mathrm{pH} 7.3,315 \mathrm{mmol} / \mathrm{kg})$. An NMDAR antagonist, $R$-CPP (2.5 $\mu \mathrm{M}$, Tocris Bioscience), was added to the potassium cutting solution to reduce glutamate receptor excitotoxicity and enhance cell survival. Slices were incubated at $32^{\circ} \mathrm{C}$ for $20 \mathrm{~min}$, and then kept at room temperature for up to $7 \mathrm{~h}$. All solutions were saturated with $95 \% \mathrm{O}_{2}$ and $5 \% \mathrm{CO}_{2}$. All procedures were performed according to guidelines approved by the Duke University Institutional Animal Care and Use Committee.

Visually guided (SliceScope Pro 2000 with Dodt-gradient contrast and water-immersion $60 \times$ objective, Scientifica) whole-cell recordings were obtained using a Multiclamp 700B (Molecular Devices) with thickwalled borosilicate glass patch pipettes (granule cells, whole cell: 5-7 M $\Omega$, granule cells, cell attached: $10-14 \mathrm{M} \Omega$, Golgi cells: $2-4 \mathrm{M} \Omega ; 1.5 \mathrm{~mm}$ OD, $0.84 \mathrm{~mm}$ ID, World Precision Instruments). Electrophysiological record-
Table 1. Convergence ratios and synaptic connection probabilities

\begin{tabular}{lccc}
\hline & $N$ & $\begin{array}{l}\text { Convergence } \\
\text { ratios }\end{array}$ & $\begin{array}{l}\text { Connection } \\
\text { probability }\end{array}$ \\
\hline $\mathrm{mf}$ & 315 & - & - \\
$\mathrm{GrC}$ & 4096 & - & - \\
$\mathrm{GoC}$ & 27 & - & - \\
$\mathrm{mf} \rightarrow \mathrm{GrC}$ & - & $4: 1$ & 0.0127 \\
$\mathrm{mf} \rightarrow \mathrm{GoC}$ & - & $10: 1$ & 0.0317 \\
$\mathrm{GoC} \rightarrow \mathrm{GrC}$ & - & $4: 1$ & 0.1481 \\
\hline
\end{tabular}

ings were performed at $32^{\circ} \mathrm{C}-33^{\circ} \mathrm{C}$, digitized at $20 \mathrm{kHz}$ (Digidata $1440 \mathrm{~A}$, Molecular Devices), and filtered at $10 \mathrm{kHz}$. Glass monopolar electrodes $(1 \mathrm{M} \Omega$ ) filled with aCSF, in conjunction with a stimulus isolation unit (ISO-Flex, A.M.P.I.), were used for extracellular stimulation of the mossy fiber tract. Cell-attached recordings were performed to avoid changes in granule cell excitability over time with whole-cell dialysis (Fleming and Hull, 2019). For these experiments, only cells with an initial spike probability in control conditions between $\sim 20 \%$ and $60 \%$ were recorded to allow for increases or decreases in spike rate during pharmacological manipulations.

sIPCSs and evoked IPSCs were recorded at the EPSC reversal potential $(10 \mathrm{mV})$. Evoked EPSCs were recorded at a holding potential of $-70 \mathrm{mV}$ and $-60 \mathrm{mV}$ for granule cells and Golgi cells, respectively. Voltageclamp recordings of IPSCs and EPSCs were collected using a cesiumbased internal solution containing the following (in $\mathrm{mM}$ ): $140 \mathrm{Cs}$ gluconate, 15 HEPES, 0.5 EGTA, 2 TEA-Cl, 2 MgATP, 0.3 NaGTP, 10 phosphocreatine-Tris ${ }_{2}$, and $2 \mathrm{QX}-314 \mathrm{Cl}$. pH was adjusted to 7.2 with $\mathrm{CsOH}$, resulting in a final osmolality of $310-315 \mathrm{mmol} / \mathrm{kg}$. Currentclamp and voltage-clamp recordings of Golgi cells were performed using a potassium-based internal solution containing the following (in $\mathrm{mM}$ ): 150 K-gluconate, $3 \mathrm{KCl}, 10 \mathrm{HEPES}, 0.5$ EGTA, $3 \mathrm{MgATP}, 0.5 \mathrm{NaGTP}, 5$ phosphocreatine-Tris 2 , and 5 phosphocreatine- $\mathrm{Na}_{2} \cdot \mathrm{pH}$ was adjusted to 7.2 with $\mathrm{KOH}$ (osmolality $315 \mathrm{mmol} / \mathrm{kg}$ ). Membrane potentials were not corrected for the liquid junction potential. Series resistance was monitored during voltage-clamp recordings with a $5 \mathrm{mV}$ hyperpolarizing pulse, and only recordings that remained stable over the period of data collection were used. All drugs were purchased from Abcam or Tocris Bioscience.

Virus injections and optogenetic experiments. Expression of the optogenetic actuator Chronos in $\mathrm{ChAT}^{+}$cerebellar projection neurons was achieved using retro-orbital injection $(2-10 \mu \mathrm{l})$ (Yardeni et al., 2011) of AAV-PHP.eb-Syn-FLEX-rc[Chronos-tdTomato] into ChAT-IRES-Cre

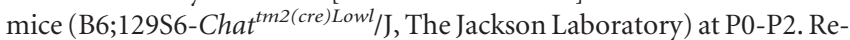
cordings with optogenetic stimulation were subsequently performed between P40 and P60. Labeled axons in these experiments were observed throughout the cerebellar vermis, including both thin fibers and mossy fiber-like axons. Mossy fiber-like axons were most dense in lobules VIII-X. Experiments were performed in any vermis lobule where labeling was evident as visualized by Td-Tomato expression during experiments. Optogenetic stimulation was performed using full-field illumination (50 $\mathrm{Hz}, 2-3 \mathrm{~s}, 10-20 \mathrm{~mW}$ ) with a $450 \mathrm{~nm}$ laser (Optoengine, MGL-III-450).

Experimental design and statistical analysis. IPSCs and EPSCs were analyzed using Clampfit, Igor Pro, and Mini Analysis software (version 6.0.3, Synaptosoft) using a $3 \mathrm{kHz}$ low-pass Butterworth filter. Detection thresholds for single-trial responses were set to $5 \times$ (IPSCs) or $2.5 \times$ (EPSCs) greater than the baseline RMS noise level. Synaptic potency was measured as the amplitude on all trials where EPSCs or IPSCs were successfully evoked according to these criteria, excluding failures. Mossy fiber paired-pulse ratios (PPRs) were determined using an interstimulus interval of $20 \mathrm{~ms}$ and measured from an average waveform across 30 consecutive trials. For voltage-clamp recordings of nicotinic and muscarinic currents, peak current amplitudes were measured from the subtracted average current for each cell. For cell-attached recordings, spike probabilities were calculated in $1 \mathrm{~ms}$ bins and normalized to the maximum spike probability in control on a per-cell basis. Because the maximum probability could occur at different times across cells, the peak value of the average normalized spike probability is $<1$. Spike rates were 
Table 2. Fixed parameters for each cell type in control conditions

\begin{tabular}{|c|c|c|c|c|c|c|c|c|c|c|c|c|}
\hline & $v_{r}(\mathrm{mV})$ & $v_{t h}(\mathrm{mV})$ & $C_{m}(\mathrm{pF})$ & $\mathrm{G}_{1}(\mathrm{nS})$ & $\mathrm{G}_{t}(\mathrm{nS})$ & $\mathrm{E}_{l}(\mathrm{mV})$ & $\mathrm{E}_{e}(\mathrm{mV})$ & $\mathrm{E}_{i}(\mathrm{mV})$ & $\sigma_{n}(\mathrm{nS})$ & $\tau_{n}(\mathrm{~ms})$ & $\tau_{e}(\mathrm{~ms})$ & $\tau_{i}(\mathrm{~ms})$ \\
\hline $\mathrm{GrC}$ & -75 & -55 & 3.1 & 0.2 & 1 & -75 & 0 & -75 & 0.05 & 20 & 12 & 20 \\
\hline $\mathrm{GOC}$ & -55 & -50 & 60 & 3 & 0 & -51 & 0 & -75 & 0.1 & 20 & 12 & 0 \\
\hline
\end{tabular}

calculated across all three stimuli in a $50 \mathrm{~ms}$ window and normalized to control. Cells from these experiments were segregated into three groups: increasing, decreasing, and cells without a significant change in baseline firing rate using a one-way $t$ test comparing baseline firing rate in control versus muscarine within each cell. Data are reported as mean \pm SEM (unless otherwise noted), and statistical analysis was performed using custom R package (available at www.github.com/trfore/MAtools) and Clampfit (Molecular Devices). Data were tested for homoscedasticity using Brown-Forsythe test and for normality via quantile-quantile plots. For heteroscedastic data, we applied a repeated-measures ANOVA with Dunnett's post hoc test; additionally, sphericity was not assumed and a Greenhouse-Geisser correction was applied. Alternatively, a one-way ANOVA with Tukey post hoc was used.

Modeling. The granular layer model was simulated with the Brian simulator (http://briansimulator.org). The structure of the network was adapted from Solinas et al. (2010), which aims to recreate a functionally relevant cube of the cerebellar granular layer with $100 \mu \mathrm{m}$ edge length. The model comprised 315 mossy fibers, 4096 granule cells, and 27 Golgi cells. Probabilistic synapses were formed using the convergence ratios in Table 1, with the probability of a particular presynaptic neuron making a connection with a particular postsynaptic neuron defined as $p=($ Conv. ratio)/(Total no. presynaptic neurons). There were no spatial constraints on synapse formation.

Granule and Golgi cells were modeled as conductance-based leaky integrate-and-fire neurons with subthreshold membrane dynamics governed by the following:

$$
C_{m} \frac{d v}{d t}=g_{l}\left(E_{l}-v\right)+\left(g_{e}+g_{n}\right)\left(E_{e}-v\right)+\left(g_{i}+g_{t}\right)\left(E_{i}-v\right)
$$

for granule cells, and

$$
C_{m} \frac{d v}{d t}=g_{l}\left(E_{l}-v\right)+\left(g_{e}+g_{n}\right)\left(E_{e}-v\right)
$$

for Golgi cells, where $C_{m}$ is the membrane capacitance; $v$ is the membrane potential; $E_{l}, E_{e}$, and $E_{i}$ are leak, excitatory, and inhibitory reversal potentials; $g_{l}, g_{e}$, and $g_{i}$ are leak, excitatory, and (phasic) inhibitory conductances; $g_{t}$ is the (fixed) tonic inhibitory conductance in granule cells; and $g_{n}$ is a stochastically fluctuating excitatory conductance described by an Ornstein-Uhlenbeck process, as follows:

$$
\tau_{n} \frac{d g_{n}}{d t}=-g_{n}+\sigma_{n} \sqrt{\tau_{n}} \xi(t)
$$

where $x(t)$ is a white noise with unit variance density. Table 2 lists the fixed parameters for each cell type in control conditions. In control, Golgi cells fired spontaneously on average between 1 and $6 \mathrm{~Hz}$. This spontaneous activity was achieved by setting the Golgi cell leak reversal $E_{l}$ near spike threshold and allowing the stochastic excitatory current to occasionally drive the cell above threshold. Application of SR95531 was simulated by eliminating both tonic and phasic inhibition onto granule cells, without changing Golgi cell excitability. Tonic release of ACh was simulated by suppressing Golgi cell activity (i.e., by setting the leak reversal back to the resting membrane potential) and reducing the magnitude of mossy fiber excitation onto both granule and Golgi cells by $54.79 \%$ and $54.22 \%$ of their control values, respectively, as per experimental results. Tonic inhibition was reduced differentially across granule cells by a fraction drawn from a gamma distribution with mean 0.6 and SD 0.07 .

Three conditions (control, SR95531, muscarine) were each simulated for 100 trials, each trial running for $2 \mathrm{~s}$. Trials were simulated for $1 \mathrm{~s}$ without mossy fiber input to allow for decorrelation of $\mathrm{GrC}$ (granule cell) and GoC (Golgi cell) populations. Mossy fiber stimulation was modeled as three spikes delivered to a random selection of 32 mossy fibers at 1.01, 1.02 , and $1.03 \mathrm{~s}$. The same 32 mossy fibers were stimulated across all trials of an individual simulation. Each mossy fiber was assigned a mean synaptic weight from a gamma distribution with a mean and SD of $0.1 \mathrm{nS}$. Following a presynaptic mossy fiber spike, excitatory postsynaptic conductance $g_{e}$ in both granule and Golgi cells was instantaneously increased by a synaptic weight drawn from a gamma distribution with mean and $\mathrm{SD}$ equal to that mossy fiber's assigned mean. A presynaptic Golgi cell spike elicited a fixed instantaneous jump in the inhibitory conductance $g_{i}$ on the postsynaptic granule cell with a $2 \mathrm{~ms}$ delay. Synaptic conductances decayed as in the following equations:

$$
\tau_{e} \frac{d g_{e}}{d t}=-g_{e}
$$

and

$$
\tau_{i} \frac{d g_{i}}{d t}=-g_{i}
$$

where $\tau_{e}$ and $\tau_{i}$ are decay time constants specific to excitation and inhibition in each cell type. Upon reaching threshold $v_{t h}$, the membrane potential was immediately reset to its resting state $v_{r}$, and held there for an absolute refractory period of 2 and $10 \mathrm{~ms}$ for granule and Golgi cells, respectively.

Excitatory and inhibitory conductance traces were recorded for each granule cell during the simulation, as well as spike times. Spike probabilities were calculated in $1 \mathrm{~ms}$ bins over the 100 trials and normalized to the peak spike probability in control on a per-cell basis. Only granule cells with active mossy fiber input and a nonzero spike probability in control were considered for subsequent analysis. To match with experimental criteria, we further selected for those cells whose peak spike probability to the second stimulus did not exceed 0.6 , and whose peak spike probability to the third stimulus did not exceed that to the second. Cells categorized as "increasing" spike probability in muscarine had a normalized spike probability $>1$, whereas "decreasing" cells had a normalized spike probability $<1$. Average conductance was calculated by integrating each conductance trace over a $60 \mathrm{~ms}$ period starting $10 \mathrm{~ms}$ before the first stimulus and ending $30 \mathrm{~ms}$ after the final stimulus, then dividing by that interval.

\section{Results}

\section{Cholinergic modulation of Golgi cells}

Anatomical studies have reported nicotinic and muscarinic receptors in the cerebellar cortex (Jaarsma et al., 1997). Additionally, functional studies have found $\alpha 7$-nAChRs (Prestori et al., 2013), $\alpha 4 \beta 2$-nAChRs, and M3-mAChRs on granule cells; however, $\alpha 4 \beta 2$-nAChRs are reportedly developmentally downregulated (Didier et al., 1995), and the M3-mAChRs are expressed in $\sim 15 \%$ of granule cells in lobules IX-X (Takayasu et al., 2003). To test for functional cholinergic receptors in the adult cerebellar granule cell layer, we performed whole-cell recordings from Golgi and granule cells in the presence of excitatory and inhibitory synaptic receptor antagonists (NBQX $5 \mu \mathrm{M}, R-\mathrm{CPP} 2.5 \mu \mathrm{M}$, and SR95531 $5 \mu \mathrm{M})$, and focally applied ACh (500 $\mu \mathrm{M}, 200 \mathrm{~ms})$ via a second pipette positioned in close proximity $(\sim 5-20 \mu \mathrm{m})$ to the recorded somata.

Golgi cells are the primary inhibitory interneuron in the granule cell layer, providing the main source of synaptic inhibition to granule cells. Because Golgi cells fire spontaneously between 1 
and $20 \mathrm{~Hz}$ (Forti et al., 2006), we first tested for ACh-mediated regulation of their spontaneous firing (Fig. 1A). Brief application of ACh caused a transient increase in the firing rates of 7 of 10 recorded Golgi cells (5.3 \pm 1.2 -fold, $n=7$ of 10; Fig. $1 B-D)$. However, in all recorded Golgi cells, there was a longer-lasting suppression of firing $(0.13 \pm 0.06$-fold, $n=10)$. To test what synaptic currents were responsible for these changes in spontaneous firing rate, we recorded in voltage-clamp configuration from a subset of the same cells. Focal application of ACh revealed a prolonged outward current that was blocked by the selective Type II muscarinic receptor antagonist AF-DX $116(1 \mu \mathrm{M}, 16.1 \pm$ $2.6 \mathrm{pA}, n=7$; Fig. $1 E, F)$, as well as a transient inward current that was blocked by the nonselective nicotinic receptor antagonist MMA $(10 \mu \mathrm{M})(40.3 \pm 11.4 \mathrm{pA}, n=7$; Fig. $1 E, F)$. In contrast, granule cell recordings revealed no change in membrane potential in response to ACh application in current clamp and no nicotinic or muscarinic receptor-activated currents in voltage clamp $(n=24$; Fig. $1 G-J)$.

Focal application of ACh onto Golgi cells suggests the possibility of long-term suppression during periods of ongoing ACh release when nicotinic receptors are desensitized. To test this, we simulated tonic release of ACh by bath application of muscarine $(10 \mu \mathrm{M})$ in the presence of TTX $(0.5 \mu \mathrm{M})$ to block spontaneous pacemaking (Fig. $2 A, B$ ). In these experiments, muscarine produced a prolonged hyperpolarization that lasted the duration of the agonist application, and was abolished in the presence of the nonselective muscarinic receptor antagonist atropine ( $5 \mu \mathrm{M}$; Fig. $2 B)$. Notably, the membrane potential returned to baseline in atropine, suggesting the absence of tonic muscarinic receptor activation in the slice. To further test whether muscarinic receptors may be activated under baseline conditions, we tested the effect of atropine on spontaneous Golgi cell spiking in the presence of excitatory and inhibitory synaptic transmission blockers (5 $\mu \mathrm{M}$ NBQX, $2.5 \mu \mathrm{M}$ R-CPP, and $5 \mu \mathrm{M}$ SR95531). These experiments revealed no significant effect of atropine on spontaneous Golgi cell spike rates ( $p=0.133$, control vs atropine; Fig. $2 C$ ), further suggesting that muscarinic receptors are not tonically activated in the slice.

To test whether such long-term Golgi cell modulation could be achieved by endogenous release of $\mathrm{ACh}$, we expressed the optogenetic actuator Chronos in cerebellar-projecting cholinergic neurons (see Materials and Methods; Fig. 2D,E) and stimulated labeled axons in cerebellar vermis using $2-3$ s pulse trains $(50 \mathrm{~Hz})$ of blue light (Fig. $2 \mathrm{~F}, \mathrm{G})$. This stimulation protocol produced a modest depolarizing current during the stimulation but predominantly resulted in a long-lasting, atropine-sensitive outward current that emerged after the stimulus and persisted for 10s of seconds (Fig. 2F,G). Overall, these findings suggest that ongoing bouts of granule cell layer ACh release can activate M2 muscarinic receptors on Golgi cells that produces a long-lasting, net suppression of these interneurons.

\section{Cholinergic regulation of granule cell tonic inhibition}

Golgi cells are the main source of granule cell synaptic inhibition (Eccles et al., 1966; Farrant and Brickley, 2003; Kanichay and Silver, 2008). Moreover, GABA released from Golgi cells activates two types of granule cell $\mathrm{GABA}_{\mathrm{A}}$ receptors to regulate granule cell excitability (Brickley et al., 1996; Crowley et al., 2009; Duguid et al., 2012, 2015). Based on our measurements of muscarinic receptor-mediated Golgi cell suppression, we next tested for changes in tonic granule cell synaptic inhibition during simulated bulk release of ACh using bath application of muscarine (Fig. $3 A, B)$. Bath application of muscarine resulted in a significant

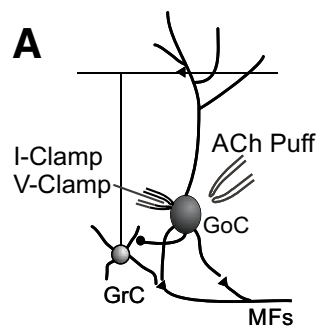

B
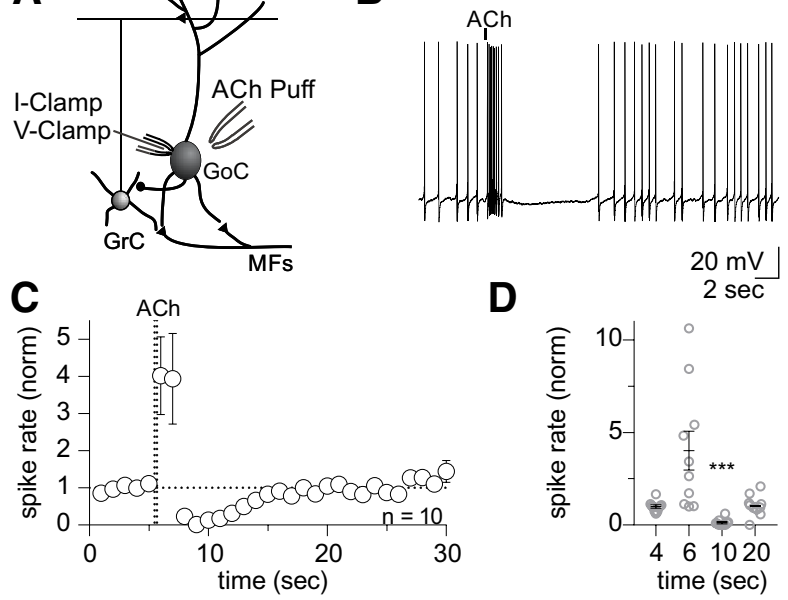

D
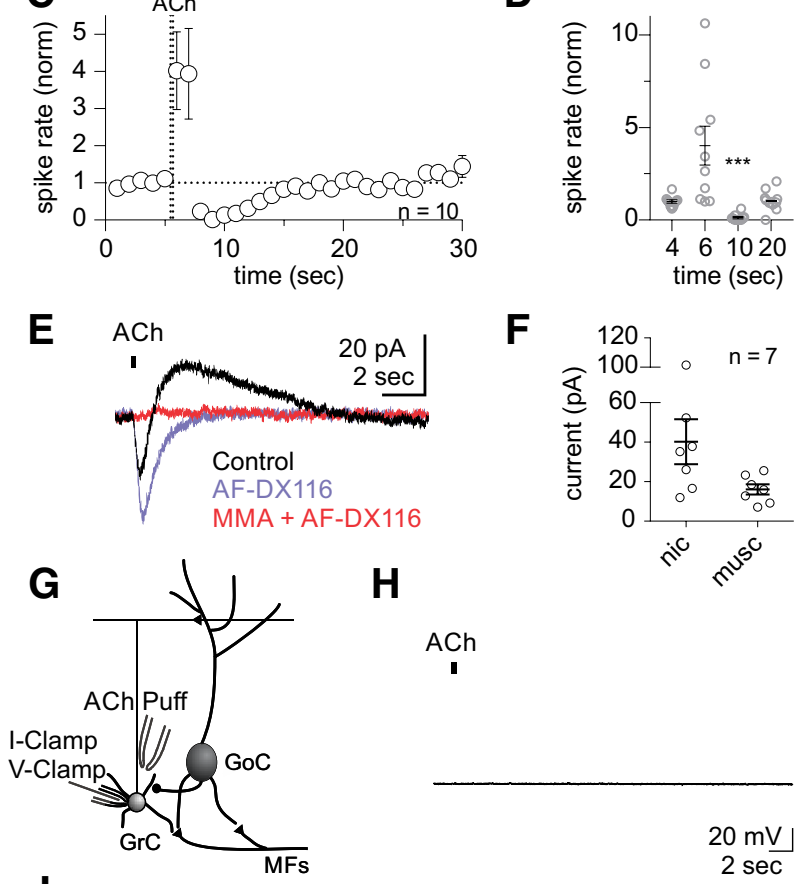

H
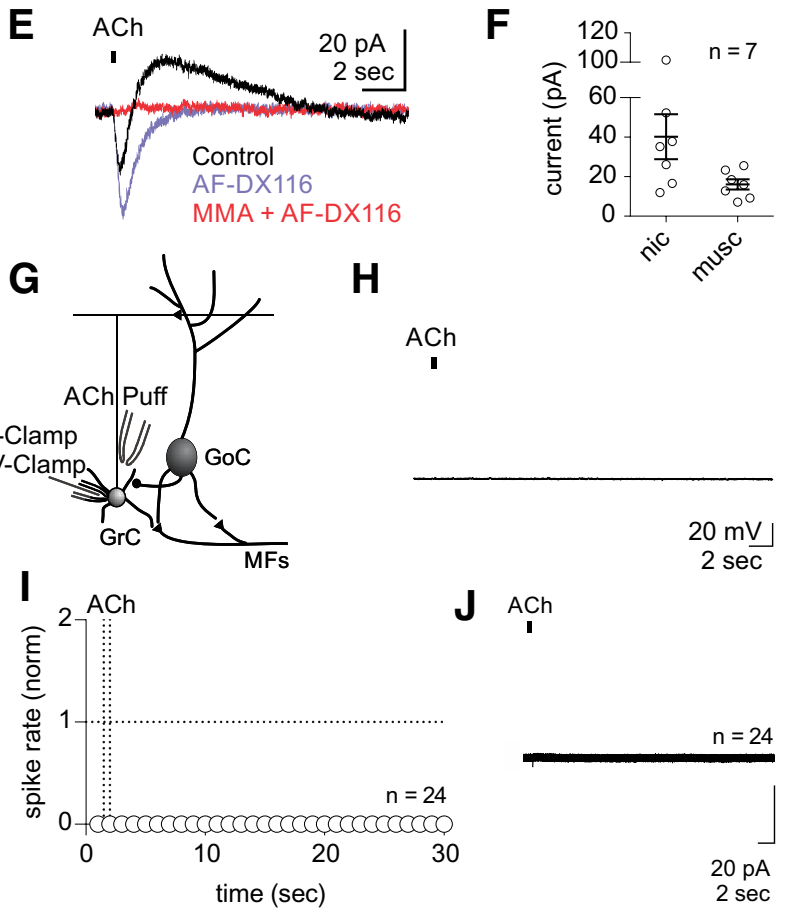

$\mathrm{ACh}$

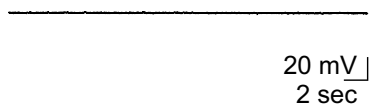

J ACh

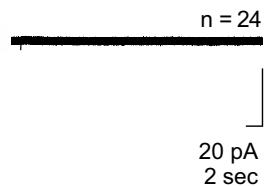

Figure 1. ACh activates nicotinic and muscarinic (M2) receptors in Golgi cells but does not act on granule cells. $A$, Schematic showing intracellular recording of Golgi cells during focal application of ACh chloride. A glass pipette containing $500 \mu \mathrm{m}$ ACh was placed in close proximity to the soma. $\boldsymbol{B}$, Representative current-clamp recording of spontaneous activity in the presence of

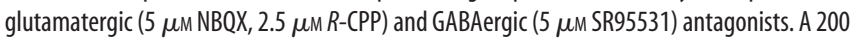
ms pulse of ACh evokes a transient increase in spontaneous spiking followed by a pause. $C, D$, Normalized spike rate across stimulus presentations (normalized to the $5 \mathrm{~s}$ period before $\mathrm{ACh}$ stimulus, $1 \mathrm{~s}$ bins, $n=10)$. C, Time course of ACh-mediated change in spike rate (group average). $\boldsymbol{D}$, Average spike rate by cell (gray), group average (black, mean \pm SEM; ANOVA, $\left.F_{(1.052,9.471)}=9.679, p=0.0111, n=10\right)$ at $4 \mathrm{~s}(0.99 \pm 0.09$ norm $), 6 \mathrm{~s}(4.0 \pm 1.1$ norm, $p=$ $0.0517), 10 \mathrm{~s}(0.1 \pm 0.06$ norm, $p=0.0004)$, and $20 \mathrm{~s}(1.1 \pm 0.2 \mathrm{norm}, p=0.9658)$. $\boldsymbol{E}$, Voltage-clamp recordings from the same cell in $\boldsymbol{B}$. A $200 \mathrm{~ms}$ pulse of ACh evokes an outward current that is blocked by a selective muscarinic M2 receptor antagonist ( $1 \mu \mathrm{M}$ AF-DX116) and an inward current that is blocked by a nonselective nicotinic antagonist (Mecamylamine hydrochloride (MMA), $10 \mu \mathrm{M}+1 \mu \mathrm{M}$ AF-DX116). F, Peak amplitudes from voltage-clamp recordings at $-60 \mathrm{mV}$. Amplitudes were determined using the baseline-subtracted average current for each cell (nicotinic: $40.3 \pm 11.4 \mathrm{pA}$, muscarinic: $16.1 \pm 2.6 \mathrm{pA}, n=7$ ). G, Schematic showing intracellular recording of granule cells during focal application of ACh. A glass pipette containing $500 \mu \mathrm{m}$ ACh was placed in close proximity to the soma. $\boldsymbol{H}$, Representative current-clamp trace from a granule cell in the presence of glutamatergic ( $5 \mu \mathrm{m} \mathrm{NBQX}, 2.5 \mu \mathrm{m} R$-CPP) and GABAergic (5 $\mu \mathrm{m}$ SR95531) antagonists. A $500 \mathrm{~ms}$ pulse of ACh fails to evoke change in the membrane potential. $I$, Average spike rate across all cells $(n=24) . J$, Grouped voltage-clamp trace from all cells $(n=24) .{ }^{* * *} p<0.001$. 

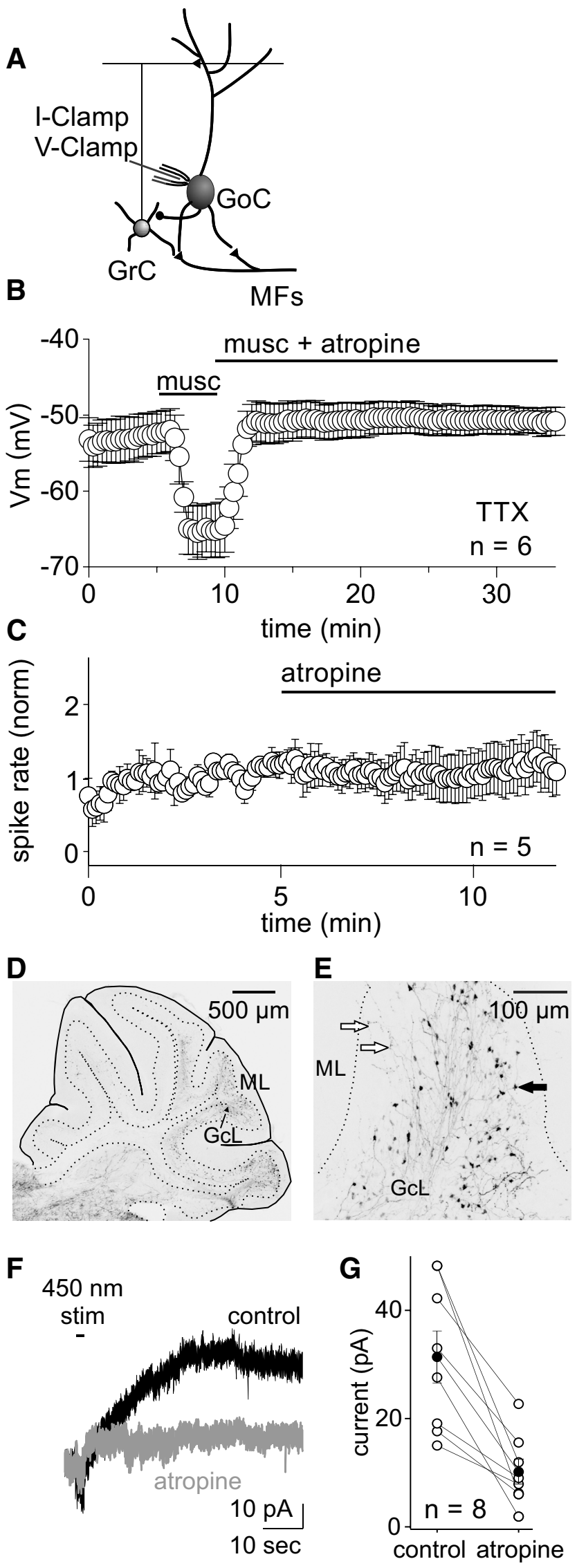

Figure 2. Activation of muscarinic receptors on Golgi cells hyperpolarizes the membrane. $\boldsymbol{A}$, Schematic showing intracellular recording of Golgi cells during bath application of muscarine (musc, $10 \mu \mathrm{m}$ ) in the presence of a voltage-activated $\mathrm{Na}^{+}{ }^{+}$channel antagonist, TTX $(0.5 \mu \mathrm{M})$, to block spontaneous firing. $\boldsymbol{B}$, Whole-cell current-clamp recordings from Golgi cells in the presence of

decrease in both sIPSC frequency $(83.7 \pm$ 2.9\% decrease, control: $4.5 \pm 0.8 \mathrm{~Hz}$, muscarine: $0.8 \pm 0.3 \mathrm{~Hz}, n=11, p<$ 0.0001; Fig. $3 C$ ) and a tonic inhibitory current mediated by nondesensitizing $\mathrm{GABA}_{\mathrm{A}}$ receptors $(54.3 \pm 3.3 \%$ decrease, control: $8.85 \pm 1.08 \mathrm{pA}$, muscarine: $4.1 \pm$ 0.7 pA, $p<0.0001$; Fig. 3D). These effects were largely reversed by atropine (sIPSC frequency: $4.9 \pm 0.9 \mathrm{~Hz}$, holding current: $7.5 \pm 1.0$ pA; Fig. $3 B-E$ ), suggesting that M2 receptor-mediated suppression of Golgi cell firing can significantly reduce tonic granule cell synaptic inhibition. Notably, atropine did not fully recover baseline levels of tonic inhibition in most cells, an effect that is consistent with the internalization of $\alpha 6$ subunit-containing $\mathrm{GABA}_{\mathrm{A}}$ receptors in response to periods of reduced GABAergic signaling (Khatri et al., 2019).

\section{Activation of Golgi cell M2 receptors induces spike rate plasticity}

In a subgroup of granule cells, sIPSC frequency increased following bath application of atropine $(1.7 \pm 0.2$ of control, $n=$ 5 of $11, p=0.015$; Fig. $3 C$ ). These data suggest an increase in spontaneous Golgi cell firing rates as a result of muscarine application. Previous work has demonstrated that Golgi cell pacemaking can undergo a form of long-term firing rate potentiation (FRP) following extended membrane hyperpolarization (Hull et al., 2013). To test whether activation of M2 receptors could provide an endogenous mechanism for inducing this plasticity, we performed whole-cell current-clamp recordings from Golgi cells in the presence of synaptic receptor antagonists $(5 \mu \mathrm{M}$ NBQX, $2.5 \mu \mathrm{M} R$-CPP, $5 \mu \mathrm{M}$ SR95531) while simulating bulk ACh release via bath application of muscarine $(10 \mu \mathrm{M}$; Fig. 4A). Muscarine reliably suppressed

$\leftarrow$

TTX to block spontaneous firing. Bath application of muscarine hyperpolarizes the membrane potential (musc: $-65.2 \pm$ $3.57 \mathrm{mV}, n=6)$. C, Whole-cell current-clamp recordings of Golgi cell spiking in the presence of NBQX $(5 \mu \mathrm{M}), R$-CPP $(2.5$ $\mu \mathrm{M})$, and SR95531 $(5 \mu \mathrm{M})$. Bath application of atropine $(5 \mu \mathrm{M})$ reveals no change in normalized spike rates $(p=0.133)$. $\boldsymbol{D}$, Expression of Chronos-TdTomato in ChAT ${ }^{+}$cerebellar projections, red fluorescence displayed in grayscale with an inverted look-up table. $\boldsymbol{E}$, Expanded view of the cerebellar cortex from $\boldsymbol{D}$. Open arrows indicate thin, beaded fibers. Closed arrow indicates mossy fiber-like projection. $\boldsymbol{F}$, Average voltage-clamp recording from an example Golgi cell $\left(V_{\mathrm{m}}=-55 \mathrm{mV}\right)$ in response to optogenetic stimulation $(450 \mathrm{~nm}, 50 \mathrm{~Hz}, 15 \mathrm{~mW}, 2 \mathrm{~s})$ in control (black) and following atropine application ( $5 \mu \mathrm{m}$, gray) $($ control average $=31.4 \pm 4.8 \mathrm{pA}$, atropine average $=$ $10.2 \pm 2.3 \mathrm{pA}, n=8, p=0.002$, paired t test). G, Summary of Golgi cell optogenetic stimulation experiments. 

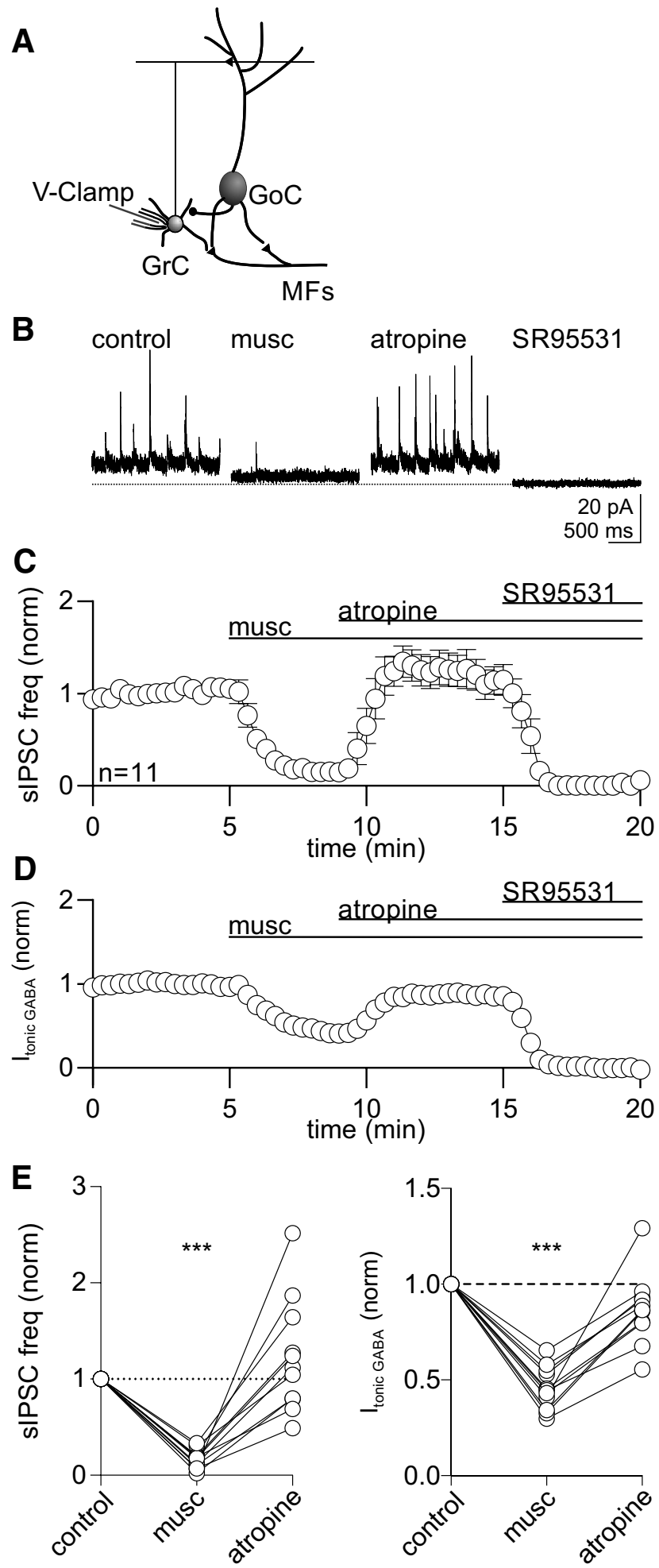

Figure 3. Activation of muscarinic $M 2$ receptors on Golgi cells decreases phasic and tonic inhibition in granule cells. $A$, Schematic showing intracellular recording of granule cells during bath application of muscarine (musc, $10 \mu \mathrm{M}$ ). $\boldsymbol{B}$, Example whole-cell voltage-clamp recording from a granule cell held at the reversal potential of excitation $(\sim 10 \mathrm{mV})$ to record $\mathrm{GABA}_{\mathrm{A}}$ receptor-mediated phasic and tonic inhibition (measured using sIPSC frequency and holding current, respectively). Dashed horizontal line indicates zero holding current. C, Grouped average sIPSC frequency across time in the presence of muscarine, atropine $(5 \mu \mathrm{m})$, and the $\mathrm{GABA}_{\mathrm{A}}$ antagonist (5 $\mu \mathrm{m}$ SR95531; mean \pm SEM, $n=11$ ). D, Grouped average holding current across time. $\boldsymbol{E}$, Left, Summary of the change in sIPSC frequency for individual cells. Quantified using a 2 min window (control: 2- 4 min, muscarine: $7-9$ min, atropine: $12-14$ min, values normalized to control; ANOVA, $\left.F_{(1.041,10.41)}=29.49, p=0.0002, n=11\right)$. Group average for each
GoC spiking throughout the application period (baseline: $4.2 \pm$ $0.6 \mathrm{~Hz}$; musc: $0.5 \pm 0.3 \mathrm{~Hz}$; Fig. $4 B$ ). Following subsequent atropine application, Golgi cell firing resumed at rates that were, on average, higher than in control $(5.5 \pm 0.7 \mathrm{~Hz}$; Fig. $4 B)$. In agreement with previous work (Hull et al., 2013), this FRP was preferential to Golgi cells with low baseline firing rates $(<5 \mathrm{~Hz}: 1.6 \pm$ 0.2 norm, $n=13$; $>5 \mathrm{~Hz}: 1.0 \pm 0.1$ norm, $n=4$; Fig. $4 C-E$ ). These results suggest that $\mathrm{ACh}$ can act as an endogenous mechanism for inducing Golgi cell FRP by activating M2 muscarinic receptors. Moreover, the diversity of plasticity across Golgi cells with different initial firing rates was in agreement with the diversity of changes in sIPSC rates in granule cells following muscarine application in atropine (Fig. 3E).

\section{Cholinergic regulation of evoked granule cell inhibition}

Golgi cells also provide evoked feedforward inhibition in response to mossy fiber activation that serves to regulate excitability during cerebellar input (Kanichay and Silver, 2008; Duguid et al., 2015). To test how evoked granule cell inhibition is regulated by ongoing cholinergic modulation, we electrically stimulated the mossy fibers during bath application of muscarine. Mossy fiber stimulation reliably evoked IPSCs (control: $51.8 \pm 8.4 \mathrm{pA}$, $12.8 \pm 5.8 \%$ failure rate, $n=5$; Fig. $5 A, B$ ). In the presence of muscarine, evoked IPSC amplitudes decreased significantly $(98.2 \pm 0.8 \%$ decrease, $0.6 \pm 0.4$ pA, $p<0.0001$; Fig. $5 B-D)$, and the failure rate increased significantly $(98.4 \pm 0.8 \%$ failure rate, $p=0.0004$; Fig. 5E). Atropine reversed these effects on the evoked IPSCs (53.0 \pm 9.9 pA; Fig. 5D) and failure rate (19.3 \pm $7.1 \%$ failure rate; Fig. $5 E$ ). Importantly, IPSCs were disynaptically evoked, as ionotropic glutamate receptor antagonists $(5 \mu \mathrm{M}$ NBQX, $2.5 \mu \mathrm{M} R$-CPP) abolished all evoked IPSCs (100 $\pm 0 \%$ failure rate; Fig. $5 E$ ). The muscarine-induced reduction in evoked IPSC amplitude and increase in failure rates are consistent with our finding of muscarinic receptor-mediated Golgi cell hyperpolarization. However, because these experiments rely on stimulated mossy fiber input, it is also possible that a muscarinic receptor-mediated reduction in presynaptic mossy fiber input to Golgi cells could also contribute to the observed reduction in evoked IPSCs.

Presynaptic muscarinic receptors reduce mossy fiber input to the granule cell layer

To test whether long-term cholinergic release could also regulate the efficacy of glutamatergic mossy fiber inputs, we next tested how bath application of muscarine regulates EPSCs onto both Golgi cells and granule cells. We first tested for the presence of muscarinic receptors at mossy fiber to Golgi cell synapses (Fig. $6 A, B)$. In response to mossy fiber stimulation, muscarine significantly decreased the amplitude of evoked EPSCs onto Golgi cells (50.7 $\pm 11.7 \%$, control: $127.0 \pm 16.6 \mathrm{pA}$, muscarine: $61.4 \pm 22.1$ pA, atropine: $120.2 \pm 18.7 \mathrm{pA}, n=10, p=0.0028$; Fig. $6 B-D)$ and increased the failure rate (control: $2.2 \pm 1.0 \%$, muscarine: $29.6 \pm 8.5 \%$, atropine: $2.2 \pm 0.6 \%, p<0.0001$; Fig. $6 E$ ). Consistent with a presynaptic effect on release probability, muscarine significantly increased the PPR of mossy fiber-evoked EPSCs

$\leftarrow$

condition: muscarine $(0.2 \pm 0.0$ norm, $p<0.0001)$; atropine $(1.2 \pm 0.2$ norm, $p=0.3773)$. Right, Summary of the change in holding current (ANOVA, $F_{(1.565,15.65)}=65.96, p<0.0001$ ) for individual cells in muscarine (group average: $0.5 \pm 0.0$ norm, $p<0.0001$ ) and atropine (group average: $0.9 \pm 0.1$ norm, $p=0.0681$ ). SIPSC and tonic inhibition was confirmed by blocking currents with the $\mathrm{GABA}_{\mathrm{A}}$ antagonist ( $5 \mu \mathrm{m}$ SR95531). ${ }^{* * *} p<0.001$. 
A

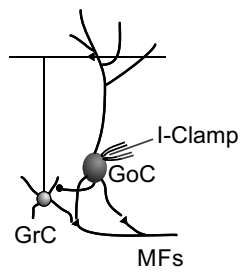

B
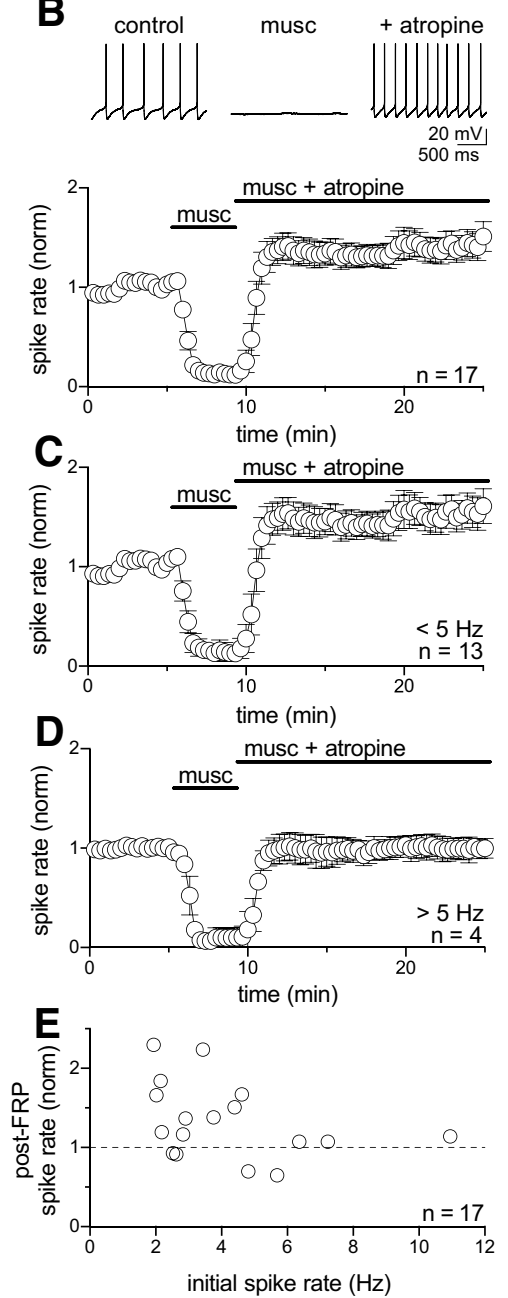

Figure 4. Activation of $M 2$ receptors on Golgi cells induces FRP. A, Schematic of intracellular current-clamp recordings from Golgi cells before and during bath application of muscarine (musc, $10 \mu \mathrm{M}$ ). B, Top, Representative current-clamp recording during muscarine application. Bath application of muscarine silences the spontaneous firing activity, and this effect is reversed with the application of atropine $(5 \mu \mathrm{M})$. Bottom, Normalized spike rate across all experiments (rate at $5 \mathrm{~min}: 4.2 \pm 0.6 \mathrm{~Hz} ; 8 \mathrm{~min}: 0.4 \pm 0.2 \mathrm{~Hz}, p<0.0001$ vs control; $20 \mathrm{~min}: 5.5 \pm 0.7 \mathrm{~Hz}$, $p=0.0284$ vs control; mean \pm SEM; ANOVA, $\left.F_{(1.602,25.62)}=35.05, p<0.0001, n=17\right) . C$, Normalized spike rate across experiments that had a baseline firing rate $<5 \mathrm{~Hz}$ (rate at $5 \mathrm{~min}$ : $3.2 \pm 0.3 \mathrm{~Hz} ; 8 \mathrm{~min}: 0.4 \pm 0.2 \mathrm{~Hz}, p<0.001$ vs control; $20 \mathrm{~min}: 4.7 \pm 0.6 \mathrm{~Hz}, p=0.0301$ vs control; ANOVA, $\left.F_{(1.729,20.75)}=35.04, p<0.0001, n=13\right)$. D , Normalized spike rate across experiments that had a baseline firing rate $>5 \mathrm{~Hz}$ (rate at $5 \mathrm{~min}: 7.7 \pm 1.5 \mathrm{~Hz} ; 8 \mathrm{~min}: 0.6 \pm 0.6$ $\mathrm{Hz}, p=0.0478$ vs control; $20 \mathrm{~min}: 7.9 \pm 1.8 \mathrm{~Hz}, p=0.8722 ;$ ANOVA, $F_{(1.068,3.205)}=12.73$, $p=0.0334, n=4)$. $\boldsymbol{E}$, Plot showing the initial spike rate and post-FRP spike rate for individual cells.

onto Golgi cells (control PPR $=1.1 \pm 0.2$, muscarine PPR $=$ $1.4 \pm 0.2, p=0.009$, one-tailed $t$ test; Fig. $6 G$ ).

To test whether presynaptic regulation of mossy fiber input is selective to Golgi cell synapses, we next measured evoked EPSCs onto granule cells during bath application of muscarine (Fig. $7 A, B)$. Again, we found a significant decrease in mossy fiber-
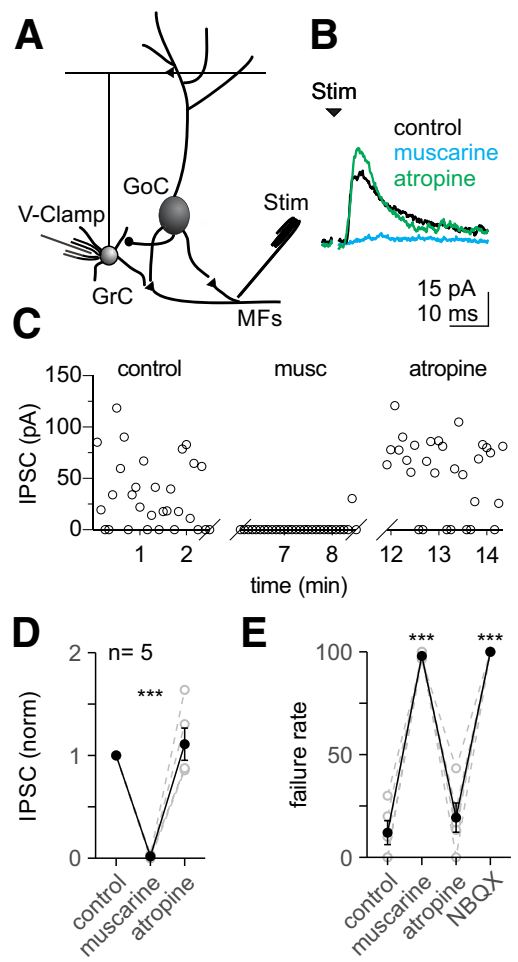

Figure 5. Reduction of feedforward inhibition by muscarinic receptors. $A$, Schematic showing the intracellular recording configuration and stimulus location, $\sim 500-1000 \mu \mathrm{m}$ from the cell. $\boldsymbol{B}$, Representative voltage-clamp recordings of IPSCS (averaged from 30 consecutive events recorded at $\sim 10 \mathrm{mV}$ ) evoked by electrical stimulation (100 $\mu$ s pulse width) of mossy fibers in control, muscarine $(10 \mu \mathrm{m})$, and atropine $(5 \mu \mathrm{M})$. C, Peak amplitude of evoked IPSCs to the first stimulus for 30 consecutive trials in each drug condition. D, E, Summary of all recorded cells. $D$, Average amplitude of the first evoked IPSC (30 consecutive trials, measurement includes successes and failures, values normalized to control) in muscarine (10 $\mu \mathrm{m}, 0.0 \pm 0.0$ norm, $p<$ $0.0001)$ and atropine ( $5 \mu \mathrm{M}, 1.1 \pm 0.2$ norm, $p=0.7283)$. Gray represents individual cells. Black lines and error bars indicate mean \pm SEM (ANOVA, $F_{(1.003 .4 .014)}=44.17, p=0.0026$, $n=5) . E$, Summary of IPSC failure rate to the first stimulus in control $(12.0 \pm 5.83 \%)$, muscarine $(10 \mu \mathrm{m}, 98.0 \pm 0.8 \%, p=0.0004)$, and atropine $(5 \mu \mathrm{m}, 19.3 \pm 7.1 \%, p=0.4479)$, and glutamate receptor antagonists (5 $\mu \mathrm{M} \mathrm{NBQX}, 2.5 \mu \mathrm{M} R$-CPP, $100.0 \pm 0.0 \%, p=0.0003$ ANOVA, $\left.F_{(1.561,6.244)}=132.8, p<0.0001\right) .{ }^{* * *} p<0.001$.

evoked EPSCs in muscarine, along with a significant increase in failure rate $(52.8 \pm 9.60 \%$ EPSC decrease, control: $68.6 \pm 10.7$ $\mathrm{pA}$, muscarine: $32.4 \pm 8.8 \mathrm{pA}, n=10$, control failure rate: $0.3 \pm$ $0.3 \%$, muscarine: $26.3 \pm 7.5 \%$; Fig. $7 B-F)$. These effects were reversed in atropine $(64.0 \pm 11.4 \mathrm{pA}$, failure rate: $1.3 \pm 0.7 \%$; Fig. $7 B-F)$. As with Golgi cell synapses, muscarine significantly increased the PPR of mossy fiber-evoked EPSCs onto granule cells (control: $0.9 \pm 0.1$ muscarine: $1.1 \pm 0.1, p=0.044$, one-tailed $t$ test; Fig. $7 G$ ). These data reveal that ongoing ACh release can reduce the efficacy of excitatory glutamatergic mossy fiber input to granule cell layer neurons by activating presynaptic muscarinic receptors.

\section{Muscarinic receptor activation produces bidirectional changes in granule cell spike probability}

Our results show that ACh can act through muscarinic receptors to reduce both incoming excitation and synaptic inhibition in the granule cell layer. To test how these effects combine at the circuit level to regulate granule cell activity, we performed noninvasive cell-attached recordings (see Materials and Methods) from granule cells while stimulating mossy fiber input (Fig. $8 A, B$ ). 

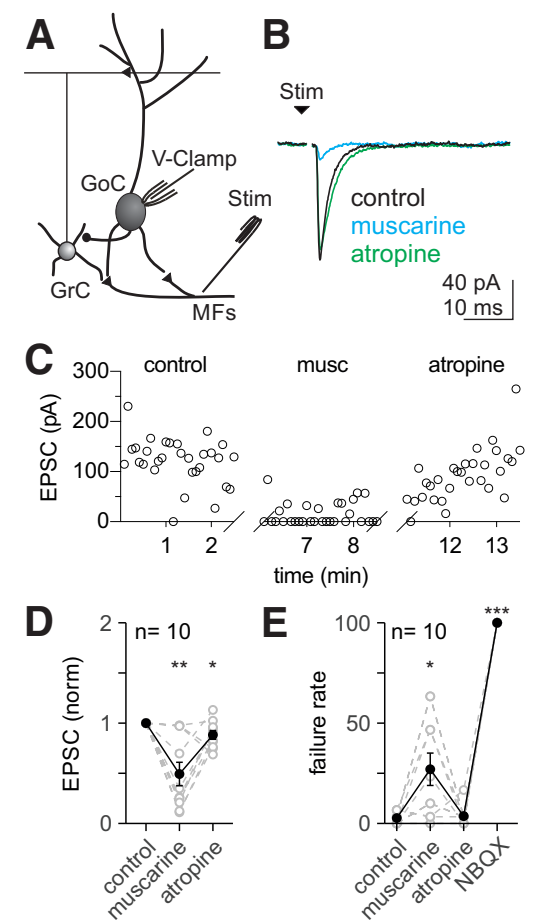

F 2$] n=10 \quad \mathbf{G}$

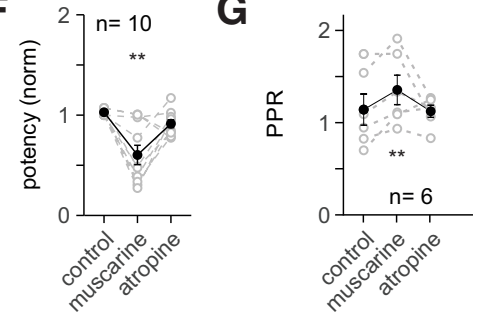

Figure 6. Activation of presynaptic muscarinic receptors alters glutamatergic transmission at the mossy fiber-Golgi cell synapse. $A$, Schematic showing the intracellular recording configuration and stimulus location. $\boldsymbol{B}$, Representative voltage-clamp recordings of EPSCs (averaged from 30 consecutive events recorded at $-60 \mathrm{mV}$ ) evoked by electrical stimulation (100 $\mu \mathrm{s}$ pulse width) of mossy fibers in control, muscarine $(10 \mu \mathrm{M})$, and atropine $(5 \mu \mathrm{M})$. C, Peak amplitude of evoked EPSCs to the first stimulus for 30 consecutive trials in each drug condition. $\mathbf{D}-\boldsymbol{F}$, Summary of all recorded cells. $\boldsymbol{D}$, Average amplitude of the first evoked EPSC (30 consecutive trials, measurement includes successes and failures, values normalized to control) in muscarine ( $10 \mu \mathrm{M}, 0.4 \pm 0.1$ norm, $p=0.0035)$ and atropine $(5 \mu \mathrm{m}, 0.9 \pm 0.0$ norm, $p=0.0439)$. Gray represents individual cells. Black lines and error bars indicate mean \pm SEM (ANOVA, $\left.F_{(1.192,10.73)}=13.58, p=0.0028, n=10\right) . E$, Summary of EPSC failure rate to the first stimulus in control $(2.2 \pm 0.96 \%)$, muscarine $(29.6 \pm 8.52 \%, p=0.0358)$, atropine $(2.2 \pm 0.6 \%, p=$ 0.8209 ), and glutamate antagonist (5 $\mu \mathrm{M} \mathrm{NBQX,} 2.5 \mu \mathrm{M} R$-CPP, $100.0 \pm 0.0 \%, p<0.0001$; ANOVA, $\left.F_{(1.063,9.565)}=120.9, p<0.0001, n=10\right)$. $\boldsymbol{F}$, Summary of EPSC potency to the first stimulus (measurement excludes event failures) in control, muscarine $(0.6 \pm 0.1 \mathrm{norm}, p=$ $0.0027)$, and atropine $\left(0.9 \pm 0.0\right.$ norm, $p=0.0792$; ANOVA, $F_{(1.345,12.11)}=13.72, p=$ 0.0017). G, Summary of PPR measured in a separate group of Golgi cells (2 pulses at $50 \mathrm{~Hz}$ ). ${ }^{*} p<0.05$. ${ }^{* *} p<0.01$. ${ }^{* *} p<0.001$.

Across eight recorded granule cells that spiked in response to mossy fiber stimulation (see Materials and Methods), bath application of muscarine produced heterogeneous effects on spike rates and spike probabilities (Fig. $8 C-I$ ). To quantify these diverse effects, we used a one-way $t$ test to identify whether each cell had a significant increase or decrease in firing rate in the presence of muscarine (significance defined as $p<0.05$ ). Three granule cells significantly increased their firing rates (control: $33.56 \pm$ $21.89 \mathrm{~Hz}$; muscarine: $64.22 \pm 34.56 \mathrm{~Hz}$; normalized change: $2.27 \pm 0.29 ; n=3$; Fig. $8 E, F$, black), three cells significantly decreased their firing rates (control: $26.22 \pm 2.44 \mathrm{~Hz}$; muscarine: $3.11 \pm 3.11 \mathrm{~Hz}$; normalized change: $0.15 \pm 0.15 ; n=3$; Fig. $8 E, F$,
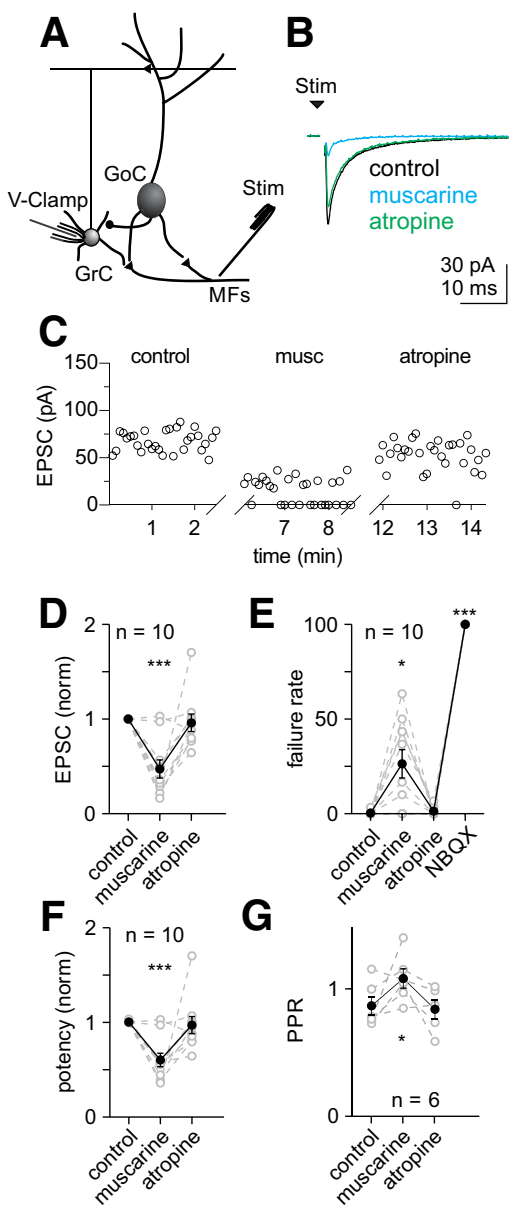

Figure 7. Activation of presynaptic muscarinic receptors reduces glutamatergic transmission at the mossy fiber-granule cell synapse. $A$, Schematic showing the intracellular recording configuration and stimulus location. $\boldsymbol{B}$, Representative voltage-clamp recordings of EPSCS (averaged from 30 consecutive events recorded at $-70 \mathrm{mV}$ ) evoked by electrical stimulation (100 $\mu$ s pulse width) of mossy fibers in control, muscarine $(10 \mu \mathrm{m})$, and atropine $(5 \mu \mathrm{m})$. C, Peak amplitude of evoked EPSCs to the first stimulus for 30 consecutive trials in each drug condition. $\boldsymbol{D}-\boldsymbol{F}$, Summary of all recorded cells. $\boldsymbol{D}$, Average amplitude of the first evoked EPSC (30 consecutive trials, measurement includes successes and failures, values normalized to control) in muscarine $(10 \mu \mathrm{m}, 0.5 \pm 0.1 \mathrm{norm}, p=0.0007)$ and atropine $(5 \mu \mathrm{m}, 1.0 \pm 0.1$ norm, $p=0.8771)$. Gray represents individual cells. Black lines and error bars indicate mean \pm SEM (ANOVA, $\left.F_{(1.65,14.85)}=14.98, p=0.0005, n=10\right) . E$, Summary of EPSC failure rate to the first stimulus in control $(0.3 \pm 0.3 \%)$, muscarine $(10 \mu \mathrm{m}, 26.3 \pm 7.5 \%, p=0.017)$, and atropine $(5 \mu \mathrm{m}$, $1.3 \pm 0.7 \%, p=0.4037)$, and glutamate antagonist ( $5 \mu \mathrm{M} \mathrm{NBQX}, 2.5 \mu \mathrm{M} C P, 100.0 \pm 0.00 \%$, $p<0.0001$; ANOVA, $\left.F_{(1.017,9.156)}=160.0, p<0.0001\right)$. $\boldsymbol{F}$, Summary of EPSC potency to the first stimulus (measurement excludes event failures) in control, muscarine $(0.6 \pm 0.1$ norm, $p=0.0007)$, and atropine (1.0 \pm 0.1 norm, $p=0.9183 ;$ ANOVA, $F_{(1.388,12.49)}=10.02, p=$ $0.0047)$. G, Summary of PPR measured in a separate group of granule cells (2 pulses at $50 \mathrm{~Hz}$ ). ${ }^{*} p<0.05$. ${ }^{* * *} p<0.001$.

orange), and two cells had no significant change (control: $19.33 \pm 8.67 \mathrm{~Hz}$; muscarine: $25.00 \pm 11.00 \mathrm{~Hz}$; normalized change: $1.30 \pm 0.01 ; n=2$, Fig. $8 E, F$, gray). These changes in firing rates were consistent with the observed changes in spike probability (Fig. $8 G, H$ ), such that the increasing cells had an increase in peak probability ( $10 \mathrm{~ms}$ bins: control: $0.63 \pm 0.09$, muscarine: $0.87 \pm 0.05, n=3$; Fig. 8 I, black) and the decreasing cells had a decrease in peak probability (control: $0.67 \pm 0.02$, muscarine: $0.13 \pm 0.08, n=3$; Fig. $8 I$, orange). However, consistent with the observation that some granule cells receive enhanced inhibition following atropine application (Fig. 4), and recovery of underlying synaptic currents can sometimes be incomplete during pharmacology experiments (Figs. 6, 7), not all 

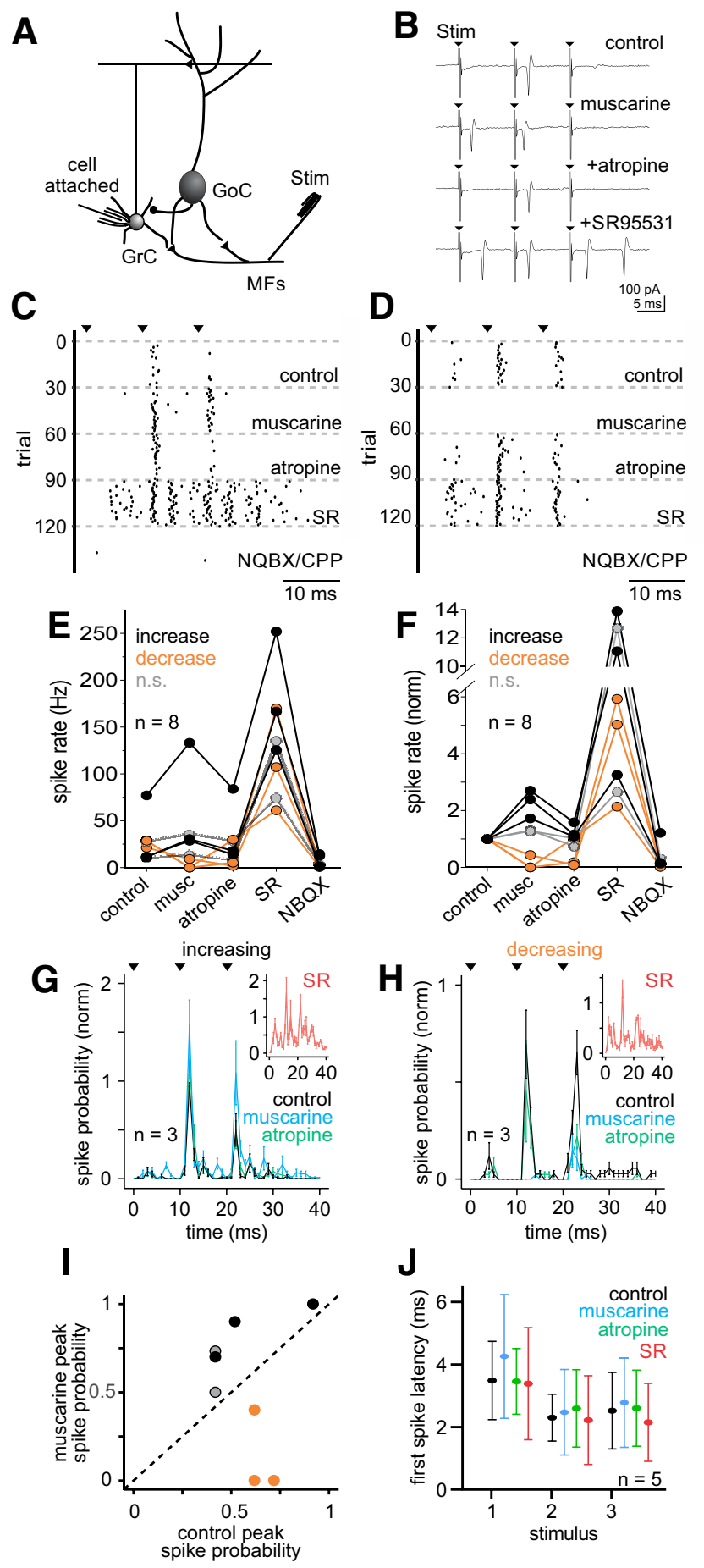

Figure 8. Muscarinic receptors bidirectionally modulate $\mathrm{GrC}$ spike probability. $\boldsymbol{A}$, Schematic showing the cell-attached recording configuration and stimulus location. $\boldsymbol{B}$, Representative cell-attached recording. Stimulus intensity was set to generate GrC spiking with 20\%-60\% probability in response to either the second or third stimulus ( 3 pulses at $100 \mathrm{~Hz}$, repeated at 0.1 Hz). C, Spike raster from an example granule cell that significantly increased spike probability in muscarine. $\boldsymbol{D}$, Spike raster from an example granule cell that significantly decreased spike probability in muscarine. $\boldsymbol{E}$, Summary of spike rates in control $(27.3 \pm 7.7 \mathrm{~Hz})$, muscarine (10 $\mu \mathrm{M}, 31.5 \pm 15.3 \mathrm{~Hz}, p=0.9763)$, atropine $(5 \mu \mathrm{M}, 23.7 \pm 9.4 \mathrm{~Hz}, p=0.8030)$, SR95531 $(5 \mu \mathrm{M}, 136.6 \pm 21.5 \mathrm{~Hz}, p=0.0016)$, and glutamatergic receptor antagonists ( $5 \mu \mathrm{MNBQX}, 2.5$ $\mu \mathrm{M} R$-CPP, $5.1 \pm 1.9 \mathrm{~Hz}, p=0.0529$; ANOVA, $\left.F_{(1.719,12.03)}=30.63, p<0.0001, n=8\right) . \boldsymbol{F}$, Summary of normalized spike rates in control, muscarine (1.2 \pm 0.4 norm, $p=0.9087)$, atropine ( $0.9 \pm 0.2$ norm, $p=0.8923)$, SR95531 (6.8 \pm 1.6 norm, $p=0.0259)$, and glutamate receptor antagonists $\left(0.3 \pm 0.1\right.$ norm, $p=0.0021$; ANOVA, $F_{(1.076,7.53)}=14.95, p=$ $0.0049, n=8$ ) for cells that significantly ( $p<0.05$ ) increased (black), decreased (orange), or did not significantly change (gray) firing rate in muscarine. $\mathbf{G}$, Summary of spike probability cells recovered control levels of spiking in atropine following muscarine application.

In contrast, blocking ionotropic GABAergic inhibition $(5 \mu \mathrm{M}$ SR95531) significantly increased spike rates uniformly across all recorded granule cells (control: $33.56 \pm 21.89 \mathrm{~Hz}$; SR95531: $136.6 \pm 21.5 \mathrm{~Hz}$; normalized change: $6.8 \pm 1.6 ; n=8$; Fig. $8 C-F$ ), with corresponding increases in spike probabilities (Fig. 8G,H, insets). Consistent with the fast membrane time constant of granule cells (Fleming and Hull, 2019), however, neither muscarine nor SR95531 altered the timing of the first spikes in response to stimulation in the five cells that maintained firing in the presence of muscarine ( $p>0.05$ for all conditions relative to control, except third stimulus in SR95531; Fig. 8J). Thus, these data suggest that muscarine can have heterogeneous effects on granule cell activity: enhancing the reliability and rate of spiking in some granule cells receiving mossy fiber input, and reducing spike probability and rate in others.

\section{Network model of granule cell spiking in response to muscarinic neuromodulation}

The difficulty of finding experimental conditions in which stimulation of the mossy fibers could drive spiking in the recorded granule cell precluded a large number of cell-attached recordings. Thus, to determine whether the observed diverse effects of muscarine are consistent with the properties of the network, and how these effects are distributed across the population, we generated a network model to determine how muscarinic neuromodulation affects population activity. This model has the added benefit of enabling us to explore how muscarine can produce such effects since it is not possible to record subthreshold excitation and inhibition across pharmacological conditions in the same granule cells with cell-attached recordings. As muscarine reduces both excitatory and inhibitory inputs to granule cells, we intuitively expected that the net effect on granule cell firing would depend on which reduction is strongest: granule cells in which excitatory inputs are more strongly reduced than inhibitory inputs should decrease their spiking activity, whereas the opposite should occur when inhibitory inputs are more strongly reduced.

To test this hypothesis, we simulated a granular layer network of 4096 granule cells and 27 Golgi cells, receiving inputs from 315 mossy fibers, with realistic connectivity parameters (see Materials and Methods). In this network simulation, we implemented all the effects of muscarine characterized above to match experimental results. Upon stimulation of a random subset of 32 mossy fibers, granule cell spiking was qualitatively similar to the slice preparation. Of the 319 granule cells that spiked in response to mossy fiber stimulation, 85 exhibited an increase in spiking activity in the simulated presence of muscarine (Fig. $9 A, C$ ), while 65 showed decreased spiking (Fig. 9B,C). The remaining granule cells did not change spike probability and were excluded from

across all granule cells that decreased spiking in muscarine $(n=3)$. Spike probability was measured by normalizing each cell to its maximum response in control. Inset, Spike probability in SR95531. $\boldsymbol{H}$, Summary of spike probability across all granule cells that decreased spiking in muscarine $(n=3)$. I, Summary of peak spike probabilities for granule cells in muscarine versus control. Peak spike probabilities: (increasing cells: control, $0.52 \pm 0.11$; muscarine, $0.7 \pm 0.05$, $n=3$; decreasing cells: control, $0.47 \pm 0.02$; muscarine, $0.08 \pm 0.04, n=3$; not significant cells: control, $0.2 \pm 0.02$; muscarine, $0.27 \pm 0.02, n=2$ ). J, Summary of the first spike latency in each drug condition (mean \pm SD stim 1: control $=3.5 \pm 1.3 \mathrm{~ms}$, musc $=4.3 \pm 2.0 \mathrm{~ms}, p=0.086$, SR95531 $=3.39 \pm 1.79 \mathrm{~ms}, p=0.790 ;$ stim $2:$ control $=2.3 \pm 0.8 \mathrm{~ms}$, musc $=2.5 \pm 1.4 \mathrm{~ms}, p=$ 0.203, SR95531 $=2.22 \pm 1.42 \mathrm{~ms}, p=0.548 ;$ stim $3:$ control $=2.5 \pm 1.2 \mathrm{~ms}$, musc $=2.8 \pm 1.4$ $\mathrm{ms}, p=0.089, \mathrm{SR} 95531=2.15 \pm 1.25 \mathrm{~ms}, p=0.006 ; n=5)$. 

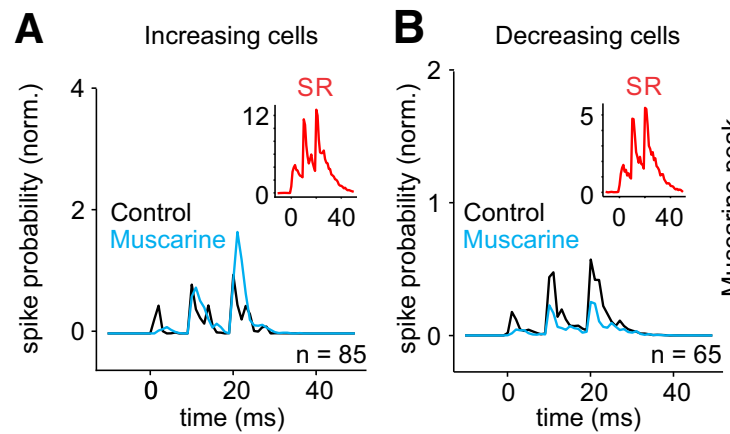

\section{C}
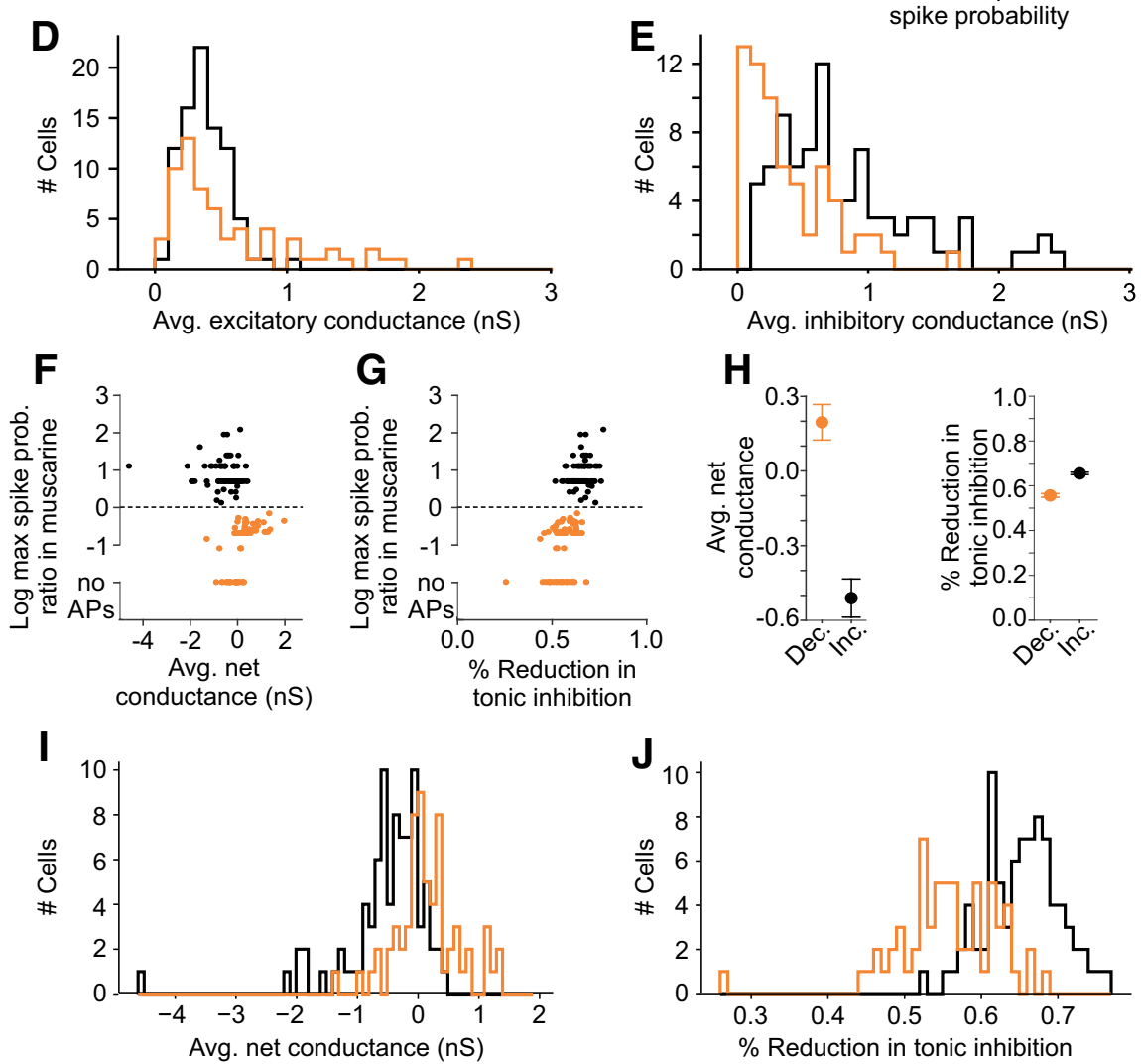

Figure 9. A computational model shows that the heterogeneity in granule cell responses can be explained by the variability in input connectivity and synaptic conductances. $\boldsymbol{A}$, Summary of spike probability across all simulated granule cells that increased spiking in muscarine. Inset, Spike probability in SR95531. B S Summary of spike probability across all simulated granule cells that decreased spiking in muscarine. Inset, Spike probability in SR95531. C, Summary of peak spike probabilities for simulated granule cells from $\boldsymbol{A}$ and $\boldsymbol{B}$ in muscarine versus control. Black represents granule cells that increased spike probability. Orange represents cells that decreased spike probability. $\boldsymbol{D}$, Distributions of average excitatory conductances in control for simulated granule cells that increased (black) or decreased (orange) spiking in muscarine. $\boldsymbol{E}$, Distributions of average inhibitory conductances in control for simulated granule cells that increased or decreased spiking in muscarine. $\boldsymbol{F}$, Summary of granule cell peak spike probability in muscarine versus average net (excitatory-inhibitory) conductance in control conditions. $\mathbf{G}$, Granule cell peak spike probability in muscarine versus fractional reduction of inhibitory tonic current. $\boldsymbol{H}$, Summary of the average net control conductance (left) and inhibitory tonic current (right) for simulated granule cells that increased or decreased spiking in muscarine. $I$, Distributions of average net input in control for simulated granule cells that increased (black) or decreased (orange) spiking in muscarine. $\boldsymbol{J}$, Distributions of fractional reduction of inhibitory tonic current in simulated granule cells that increased or decreased spiking in muscarine.

further analysis. Thus, this network recapitulates the heterogeneity observed in our cell-attached recordings.

We next investigated the conditions that biased cells toward an increase or decrease in firing in muscarine. We found that there was a significant difference in the distributions of excitatory and inhibitory conductances for granule cells that increased or decreased spike probability in muscarine (excitatory conductance; Kolmogorov-Smirnov D =0.28, $p<0.01$;
Fig. 9D; inhibitory conductance; Kolmogorov-Smirnov D $=0.43, p<0.01, \mathrm{KS}$ test; Fig. 9E). Overall, cells exhibiting an increase in spike probability were dominated by inhibition in control conditions (net conductance: $-0.51 \pm 0.08 \mathrm{nS}$; Fig. $9 F, H, I)$, whereas cells with decreasing spike probability received relatively less Golgi cell input (net conductance: $0.20 \pm$ 0.07 nS; Fig. 9 F, H, I; net conductance for increasing vs decreasing: KolmogorovSmirnov D $=0.53, p<0.0001$; Fig. 9I). Moreover, there was a preferentially greater reduction in tonic inhibition of cells with increased spiking activity (increasing: $65.5 \pm 1 \%$ reduction; decreasing: $55.7 \pm 1 \%$ reduction, KolmogorovSmirnov D $=0.62, p<0.0001$; Fig. $9 F, H, J)$.

We tested that our results did not depend on a specific realization of the network connectivity by simulating 30 independent realizations of the connectivity matrix, and patterns of input mossy fiber stimulation. While the relative numbers of cells exhibiting increases and decreases in spike probability were variable across different instantiations of the model, the underlying input profiles distinguishing the two cell categories were comparable (increasing cells had a net inhibitory conductance in control: $-0.40 \pm$ $0.03 \mathrm{nS}$; decreasing cells had a net excitatory conductance in control: $0.26 \pm 0.03$ $\mathrm{nS}$; data not shown). Similarly, we saw consistently larger decreases in the inhibitory tonic current for cells that increased their spike probability in muscarine (increasing: $64.7 \pm 0.2 \%$ reduction; decreasing: $57.6 \pm 0.2 \%$ reduction; data not shown). Together, these results indicate that muscarinic neuromodulation preferentially enhances the spike rates of granule cells with larger synaptic inhibition in control conditions.

\section{Discussion}

Here we have shown that ACh activates muscarinic receptors to modulate two of the three main nodes within the granule cell layer of the cerebellar cortex. Specifically, both Golgi cells and mossy fibers express muscarinic receptors that serve to hyperpolarize Golgi cells and decrease mossy fiber release probability, respectively. By simulating ongoing release of ACh using bath application of muscarine, we revealed a suppression of Golgi cell spiking that is mediated by M2-type muscarinic receptors. Consistent with this finding, optogenetic stimulation of $\mathrm{ChAT}^{+}$cerebellar projections produced a long-lasting, net hyperpolarizing current in Golgi cells that greatly outlasted the duration of stimulation. At the circuit level, suppression of Golgi spiking led to a large decrease in synaptic inhibition onto granule 
cells. In parallel, muscarine also reduced excitatory transmission from mossy fibers by acting on presynaptic muscarinic receptors.

Together, by acting on both Golgi cells and mossy fibers, we find that ACh can alter the coordination of excitation and inhibition onto granule cells. Surprisingly, however, these changes in excitation and inhibition produce diverse changes in granule cell spiking at the population level. Specifically, spike probability in some granule cells can be enhanced, whereas others are largely suppressed. By generating a network model of the granule cell layer, we provide evidence that the direction of spike rate modulation is established by the initial balance of excitation and inhibition onto each cell, as well as the degree to which neuromodulation reduces tonic inhibition. Overall, cells with higher levels of inhibition increased their spike rates in response to neuromodulation, whereas cells with less inhibition decreased their spike rates. Because cells that decreased their firing rate were excitation-dominated, they also tended to have the highest firing rates before cholinergic neuromodulation. These changes are in stark contrast to the responses observed after removing all inhibition, which dramatically increases spiking of the entire population. Thus, these data suggest that, by simultaneously reducing excitation and inhibition, cholinergic neuromodulation can provide a mechanism for enhancing the responses of subsets of granule cells without expanding the overall population response.

Under what conditions might ACh act to modulate the granule cell layer in vivo? Previous work suggests that $\mathrm{ChAT}^{+}$ cerebellar-projecting neurons originate from diverse sources (Jaarsma et al., 1997). Consistent with our findings, these projections can take the form of mossy fiber-like inputs or thinner beaded fibers (Jaarsma et al., 1997). Previous studies have shown that $\mathrm{ChAT}^{+}$mossy fiber terminals and beaded fibers are expressed throughout the cerebellar cortex, with lobules IX/X having the densest mossy fiber innervation and lobule IX having the densest beaded fiber innervation (Ojima et al., 1989; Barmack et al., 1992a; Jaarsma et al., 1996). We also observed the densest innervation of $\mathrm{ChAT}^{+}$mossy fiber-like terminals in these lobules, although $\mathrm{ChAT}^{+}$terminals were present in all lobules, and we observed optogenetically driven currents in Golgi cells throughout the vermis. Anatomical studies have suggested that the $\mathrm{ChAT}^{+}$MFs located in lobules IX/X and the flocculus originate from medial vestibular nucleus and nucleus prepositus hypoglossi (Barmack et al., 1992b), whereas $\mathrm{ChAT}^{+}$beaded fibers may originate from the pedunculopontine tegmental nuclei (PPTg) (Woolf and Butcher, 1989; Newman and Ginsberg, 1992; Ruggiero et al., 1997). Notably, for any of these sources, it remains possible that other neurotransmitters are coreleased with $\mathrm{ACh}$, as has been shown in other brain regions (Granger et al., 2017). However, based on our goal of measuring the longer timescale effects of $\mathrm{ACh}$, we did not investigate the possibility of other fast transmitters that may also play a role during the initial phases of transient ACh release.

Such diversity of sources of ACh suggests multiple roles for cholinergic signaling. Inputs from the medial vestibular nucleus are likely to be important for modulation of vestibular guided reflexes. In support of such a role for ACh, previous work has shown that cerebellar injection of cholinergic agonists can enhance both optokinetic and vestibulo-ocular reflexes (Tan and Collewijn, 1991, 1992; Prestori et al., 2013).

The presence of cholinergic inputs from the PPTg also suggests a role for ACh in contextual modulation of the granule cell layer, for instance by arousal or locomotion. Indeed, recent work has demonstrated a locomotion-dependent enhancement of learning in a cerebellar-dependent form of delay eyeblink conditioning (Albergaria et al., 2018). Specifically, the acquisition rate of delay eyeblink conditioning was correlated with the animals' running speed. In this study, the circuit mechanism underlying this enhancement was linked to an increase in granule cell layer excitability (Albergaria et al., 2018). In this model, behaviorally relevant sensory information would more easily drive granule cells past spike threshold during locomotion, and thus transmit more effectively to downstream Purkinje cells to promote synaptic plasticity and learning. While speculative, our results suggest the possibility that ACh could provide an endogenous mechanism to disinhibit populations of granule cells and enable such locomotion-dependent effects on learning. In particular, because the PPTg is active during locomotion (Lee et al., 2014), it could provide the type of tonic ACh release that would enhance granule cell responses and promote associative learning. At present, however, it is unknown whether ACh is released into the cerebellar cortex during locomotion as it is in other brain regions.

Finally, our results suggest that the key determinant of how ACh modulates granule cell spike probability is the initial balance of excitation and inhibition onto each cell. Indeed, previous work has demonstrated that inhibition is not homogeneous across granule cells (Crowley et al., 2009). Such diversity may arise from a combination of factors, including differences in the number of Golgi cell inputs per glomerulus (Jakab and Hamori, 1988), the number of granule cell dendrites per cell (Palay and Chan-Palay, 1974), a diversity of Golgi cell types (Neki et al., 1996; Geurts et al., 2001; Simat et al., 2007), or differences in GABA receptor expression at granule cell synapses (Wall, 2002). Likewise, the amplitude of unitary excitatory mossy fiber conductances onto granule cells has been shown to vary over a wide range, and depend on the source of the mossy fiber input (Chabrol et al., 2015). Moreover, because granule cells can integrate multiple mossy fiber inputs from diverse sources (Huang et al., 2013), it is possible for individual cells to exhibit considerable variability in both the amount of excitation and inhibition they receive across the population.

Notably, we find that ACh selectively increases the excitability of the granule cells that are most strongly inhibited. Previous work has suggested that granule cell inhibition can be stimulusspecific (Precht and Llinás, 1969), and recent work has indicated that such stimulus-specific inhibition may play a key role in cerebellar learning (Kalmbach et al., 2011). If different Golgi cells can indeed be recruited by some stimuli and not others, cholinergic neuromodulation would provide an ideal mechanism to enhance the responses of granule cells that would otherwise be suppressed by stimulus-specific inhibition. Hence, such a mechanism could serve to enhance learning for specific mossy fiber inputs, perhaps based on behavioral context or stimulus salience. Thus, ACh neuromodulation would provide an appealing means to regulate learning or modify the gain of cerebellar transformations. While future in vivo experiments will be necessary to evaluate this possibility, our results reveal both the cell-autonomous and circuit-level actions by which ongoing ACh release can act through muscarinic receptors to modulate granule cell excitability. Such data thus provide the foundation for interpreting the in vivo effects of cholinergic neuromodulation at the input stage of cerebellar processing. 


\section{References}

Albergaria C, Silva NT, Pritchett DL, Carey MR (2018) Locomotor activity modulates associative learning in mouse cerebellum. Nat Neurosci 21:725-735.

Albus JS (1971) A theory of cerebellar function. Math Biosci 10:25-61.

Barmack NH, Baughman RW, Eckenstein FP (1992a) Cholinergic innervation of the cerebellum of rat, rabbit, cat, and monkey as revealed by choline acetyltransferase activity and immunohistochemistry. J Comp Neurol 317:233-249.

Barmack NH, Baughman RW, Eckenstein FP, Shojaku H (1992b) Secondary vestibular cholinergic projection to the cerebellum of rabbit and rat as revealed by choline acetyltransferase immunohistochemistry, retrograde and orthograde tracers. J Comp Neurol 317:250-270.

Brickley SG, Cull-Candy SG, Farrant M (1996) Development of a tonic form of synaptic inhibition in rat cerebellar granule cells resulting from persistent activation of GABAA receptors. J Physiol 497:753-759.

Cayco-Gajic NA, Clopath C, Silver RA (2017) Sparse synaptic connectivity is required for decorrelation and pattern separation in feedforward networks. Nat Commun 8:1116.

Chabrol FP, Arenz A, Wiechert MT, Margrie TW, DiGregorio DA (2015) Synaptic diversity enables temporal coding of coincident multisensory inputs in single neurons. Nat Neurosci 18:718-727.

Crowley JJ, Fioravante D, Regehr WG (2009) Dynamics of fast and slow inhibition from cerebellar Golgi cells allow flexible control of synaptic integration. Neuron 63:843-853.

Didier M, Berman SA, Lindstrom J, Bursztajn S (1995) Characterization of nicotinic acetylcholine receptors expressed in primary cultures of cerebellar granule cells. Brain Res Mol Brain Res 30:17-28.

Dominguez de Toro ED, Juíz JM, Smillie FI, Lindstrom J, Criado M (1997) Expression of $\alpha 7$ neuronal nicotinic receptors during postnatal development of the rat cerebellum. Dev Brain Res 98:125-133.

Dominguez del Toro E, Juiz JM, Peng X, Lindstrom J, Criado M (1994) Immunocytochemical localization of the alpha 7 subunit of the nicotinic acetylcholine receptor in the rat central nervous system. J Comp Neurol 349:325-342.

Dugué GP, Dumoulin A, Triller A, Dieudonné S (2005) Target-dependent use of co-released inhibitory transmitters at central synapses. J Neurosci 25:6490-6498.

Duguid I, Branco T, London M, Chadderton P, Häusser M (2012) Tonic inhibition enhances fidelity of sensory information transmission in the cerebellar cortex. J Neurosci 32:11132-11143.

Duguid I, Branco T, Chadderton P, Arlt C, Powell K, Häusser M (2015) Control of cerebellar granule cell output by sensory-evoked Golgi cell inhibition. Proc Natl Acad Sci U S A 112:13099-13104.

Eccles JC, Llinás R, Sasaki K (1966) The mossy fibre-granule cell relay of the cerebellum and its inhibitory control by Golgi cells. Exp Brain Res 1:82101.

Farrant M, Brickley SG (2003) Properties of GABA(A) receptor-mediated transmission at newly formed Golgi-granule cell synapses in the cerebellum. Neuropharmacology 44:181-189.

Fleming E, Hull C (2019) Serotonin regulates dynamics of cerebellar granule cell activity by modulating tonic inhibition. J Neurophysiol 121:105114.

Forti L, Cesana E, Mapelli J, D’Angelo E (2006) Ionic mechanisms of autorhythmic firing in rat cerebellar Golgi cells. J Physiol 574:711-729.

Froemke RC, Carcea I, Barker AJ, Yuan K, Seybold BA, Martins AR, Zaika N, Bernstein H, Wachs M, Levis PA, Polley DB, Merzenich MM, Schreiner CE (2013) Long-term modification of cortical synapses improves sensory perception. Nat Neurosci 16:79-88.

Geurts FJ, Timmermans J, Shigemoto R, De Schutter E (2001) Morphological and neurochemical differentiation of large granular layer interneurons in the adult rat cerebellum. Neuroscience 104:499-512.

Gilmer JI, Person AL (2017) Morphological constraints on cerebellar granule cell combinatorial diversity. J Neurosci 37:12153-12166.

Giovannucci A, Badura A, Deverett B, Najafi F, Pereira TD, Gao Z, Ozden I, Kloth AD, Pnevmatikakis E, Paninski L, De Zeeuw CI, Medina JF, Wang SS (2017) Cerebellar granule cells acquire a widespread predictive feedback signal during motor learning. Nat Neurosci 20:727734.

Granger AJ, Wallace ML, Sabatini BL (2017) Multi-transmitter neurons in the mammalian central nervous system. Curr Opin Neurobiol 45:85-91.

Huang CC, Sugino K, Shima Y, Guo C, Bai S, Mensh BD, Nelson SB, Hant- man AW (2013) Convergence of pontine and proprioceptive streams onto multimodal cerebellar granule cells. Elife 2:e00400.

Hull CA, Chu Y, Thanawala M, Regehr WG (2013) Hyperpolarization induces a long-term increase in the spontaneous firing rate of cerebellar Golgi cells. J Neurosci 33:5895-5902.

Ito M (2006) Cerebellar circuitry as a neuronal machine. Prog Neurobiol $78: 272-303$.

Ito M (2012) The cerebellum, pp. 1-285. Upper Saddle River, NJ: FT.

Jaarsma D, Diño MR, Cozzari C, Mugnaini E (1996) Cerebellar choline acetyltransferase positive mossy fibres and their granule and unipolar brush cell targets: a model for central cholinergic nicotinic neurotransmission. J Neurocytol 25:829-842.

Jaarsma D, Ruigrok TJ, Caffé R, Cozzari C, Levey AI, Mugnaini E, Voogd J (1997) Cholinergic innervation and receptors in the cerebellum. Prog Brain Res 114:67-96.

Jakab RL, Hamori J (1988) Quantitative morphology and synaptology of cerebellar glomeruli in the rat. Anat Embryol (Berl) 179:81-88.

Kalmbach BE, Voicu H, Ohyama T, Mauk MD (2011) A subtraction mechanism of temporal coding in cerebellar cortex. J Neurosci 31:2025-2034

Kanichay RT, Silver RA (2008) Synaptic and cellular properties of the feedforward inhibitory circuit within the input layer of the cerebellar cortex. J Neurosci 28:8955-8967.

Khatri SN, Wu WC, Yang Y, Pugh JR (2019) Mechanisms of GABAB receptor enhancement of extrasynaptic GABAA receptor currents in cerebellar granule cells. Sci Rep 9:16683.

Kuchibhotla KV, Gill JV, Lindsay GW, Papadoyannis ES, Field RE, Sten TA, Miller KD, Froemke RC (2017) Parallel processing by cortical inhibition enables context-dependent behavior. Nat Neurosci 20:62-71.

Lee AM, Hoy JL, Bonci A, Wilbrecht L, Stryker MP, Niell CM (2014) Identification of a brainstem circuit regulating visual cortical state in parallel with locomotion. Neuron 83:455-466.

Letzkus JJ, Wolff SB, Meyer EM, Tovote P, Courtin J, Herry C, Lüthi A (2011) A disinhibitory microcircuit for associative fear learning in the auditory cortex. Nature 480:331-335.

Marr D (1969) A theory of cerebellar cortex. J Physiol 202:437-470.

Mauk MD, Buonomano DV (2004) The neural basis of temporal processing. Annu Rev Neurosci 27:307-340.

Nakayama H, Shioda S, Nakajo S, Ueno S, Nakashima T, Nakai Y (1997) Immunocytochemical localization of nicotinic acetylcholine receptor in the rat cerebellar cortex. Neurosci Res 29:233-239.

Neki A, Ohishi H, Kaneko T, Shigemoto R, Nakanishi S, Mizuno N (1996) Metabotropic glutamate receptors mGluR2 and mGluR5 are expressed in two non-overlapping populations of Golgi cells in the rat cerebellum. Neuroscience 75:815-826.

Neustadt A, Frostholm A, Rotter A (1988) Topographical distribution of muscarinic cholinergic receptors in the cerebellar cortex of the mouse, rat, guinea pig, and rabbit: a species comparison. J Comp Neurol 272: 317-330.

Newman DB, Ginsberg CY (1992) Brainstem reticular nuclei that project to the cerebellum in rats: a retrograde tracer study. Brain Behav Evol 39:2468.

Ojima H, Kawajiri S, Yamasaki T (1989) Cholinergic innervation of the rat cerebellum: qualitative and quantitative analyses of elements immunoreactive to a monoclonal antibody against choline acetyltransferase. J Comp Neurol 290:41-52.

Ozden I, Dombeck DA, Hoogland TM, Tank DW, Wang SS (2012) Widespread state-dependent shifts in cerebellar activity in locomoting mice. PLoS One 7:e42650.

Palay SL, Chan-Palay V (1974) Cerebellar cortex. New York: Springer.

Precht W, Llinás R (1969) Functional organization of the vestibular afferents to the cerebellar cortex of frog and cat. Exp Brain Res 9:30-52.

Prestori F, Bonardi C, Mapelli L, Lombardo P, Goselink R, De Stefano ME, Gandolfi D, Mapelli J, Bertrand D, Schonewille M, De Zeeuw C, D’Angelo E (2013) Gating of long-term potentiation by nicotinic acetylcholine receptors at the cerebellum input stage. PLoS One 8:e64828.

Ruggiero DA, Anwar M, Golanov EV, Reis DJ (1997) The pedunculopontine tegmental nucleus issues collaterals to the fastigial nucleus and rostral ventrolateral reticular nucleus in the rat. Brain Res 760:272-276.

Simat M, Parpan F, Fritschy JM (2007) Heterogeneity of glycinergic and GABAergic interneurons in the granule cell layer of mouse cerebellum. J Comp Neurol 500:71-83. 
Solinas S, Nieus T, D'Angelo E (2010) A realistic large-scale model of the cerebellum granular layer predicts circuit spatio-temporal filtering properties. Front Cell Neurosci 4:12.

Takayasu Y, Iino M, Furuya N, Ozawa S (2003) Muscarine-induced increase in frequency of spontaneous EPSCs in Purkinje cells in the vestibulocerebellum of the rat. J Neurosci 23:6200-6208.

Tan HS, Collewijn H (1991) Cholinergic modulation of optokinetic and vestibulo-ocular responses: a study with microinjections in the flocculus of the rabbit. Exp Brain Res 85:475-481.

Tan HS, Collewijn H (1992) Cholinergic and noradrenergic stimulation in the rabbit flocculus have synergistic facilitatory effects on optokinetic responses. Brain Res 586:130-134.
Turner JR, Kellar KJ (2005) Nicotinic cholinergic receptors in the rat cerebellum: multiple heteromeric subtypes. J Neurosci 25:9258-9265.

Wagner MJ, Kim TH, Savall J, Schnitzer MJ, Luo L (2017) Cerebellar granule cells encode the expectation of reward. Nature 544:96-100.

Wall MJ (2002) Furosemide reveals heterogeneous GABA(A) receptor expression at adult rat Golgi cell to granule cell synapses. Neuropharmacology 43:737-749.

Woolf NJ, Butcher LL (1989) Cholinergic systems in the rat brain: IV. Descending projections of the pontomesencephalic tegmentum. Brain Res Bull 23:519-540.

Yardeni T, Eckhaus M, Morris HD, Huizing M, Hoogstraten-Miller S (2011) Retro-orbital injections in mice. Lab Anim (NY) 40:155-160. 